\title{
Comprehensive genotype-phenotype correlation in lissencephaly
}

\author{
Ai Peng Tan ${ }^{1,2}$, Wui Khean Chong ${ }^{3}$, Kshitij Mankad ${ }^{3}$ \\ ${ }^{1}$ Department of Diagnostic Imaging, National University Health System, Singapore; ${ }^{2}$ Yong Loo Lin School of Medicine, National University of \\ Singapore (NUS), Singapore; ${ }^{3}$ Department of Neuroradiology, Great Ormond Street Hospital NHS Foundation Trust, London, UK \\ Correspondence to: Ai Peng Tan, MD, MMed (Diag Radiol), FRCR. Department of Diagnostic Imaging, National University Health System, 1E Kent \\ Ridge Rd, 119228 Singapore. Email: ai_peng_tan@nuhs.edu.sg.
}

\begin{abstract}
Malformations of cortical development (MCD) are a heterogenous group of disorders with diverse genotypic and phenotypic variations. Lissencephaly is a subtype of MCD caused by defect in neuronal migration, which occurs between 12 and 24 weeks of gestation. The continuous advancement in the field of molecular genetics in the last decade has led to identification of at least 19 lissencephaly-related genes, most of which are related to microtubule structural proteins (tubulin) or microtubule-associated proteins (MAPs). The aim of this review article is to bring together current knowledge of gene mutations associated with lissencephaly and to provide a comprehensive genotype-phenotype correlation. Illustrative cases will be presented to facilitate the understanding of the described genotype-phenotype correlation.
\end{abstract}

Keywords: Lissencephaly (LIS); LIS1; doublecortin (DCX); tubulinopathy

Submitted Jul 11, 2018. Accepted for publication Aug 15, 2018.

doi: 10.21037/qims.2018.08.08

View this article at: http://dx.doi.org/10.21037/qims.2018.08.08

\section{Introduction}

The rapidly evolving genetic landscape has revealed more than 100 genes associated with malformations of cortical development (MCD), a heterogeneous group of disorders with diverse genotypic and phenotypic variations. Substantial insights into the mechanisms underlying lissencephaly (LIS) led most to believe that these processes map onto molecular processes/pathways and are interdependent on one another, explaining the wide array of clinical and imaging phenotypes. The cerebral cortex comprises of two groups of neurons with differing migration modes: (I) radial migration from the ventricular zone and (II) tangential migration from ganglionic eminence. Neurons that undergo radial migration are primarily excitatory projection neurons while neurons that migrate in a tangential manner are mainly inhibitory interneurons.

LIS1 and DCX are the commonest LIS-related gene mutations, first discovered in 1993 and 1998 respectively (1-3). The continuous advancement in the field of molecular genetics in the last decade has led to identification of 19 LIS-associated genes thus far, many of which are related to microtubule structural proteins (tubulin) or microtubuleassociated proteins (MAPs) (4). These LIS-related genes include LIS1, DCX, ACTB, ACTG1, ARX, CDK5, CRADD, DYNC1H1, KIF2A, KIF5C, NDE1/NDEL1, TUBA1A, TUBA8, TUBB, TUBB2B, TUBB3, TUBG1, RELN and $\operatorname{VLDLR}(2,5-15)$ (Figure 1). In view of the rapidly expanding LIS-related genetic mutations and heterogeneous phenotypes, a more comprehensive classification system is crucial. Just recently, a new imaging-based classification system for LIS was proposed by Di Donato et al. (4).

A comprehensive analysis of clinical features, familial distribution (if present) and neuroimaging findings is crucial to facilitate a more targeted genetic testing in patients with LIS. For instance, an X-linked pattern of inheritance would suggest the involvement of $D C X$ or $A R X$ genes while an autosomal recessive pattern of inheritance would suggest involvement of reelin-pathway-related genes or the CDK5 gene. LIS and facial dysmorphism are characteristics of Miller-Dieker syndrome (MDS), Baraitser-Winter syndrome (BWS) and Norman Roberts syndrome (NRS). On the other hand, the presence of genital abnormality such as cryptorchidism, micropenis and 


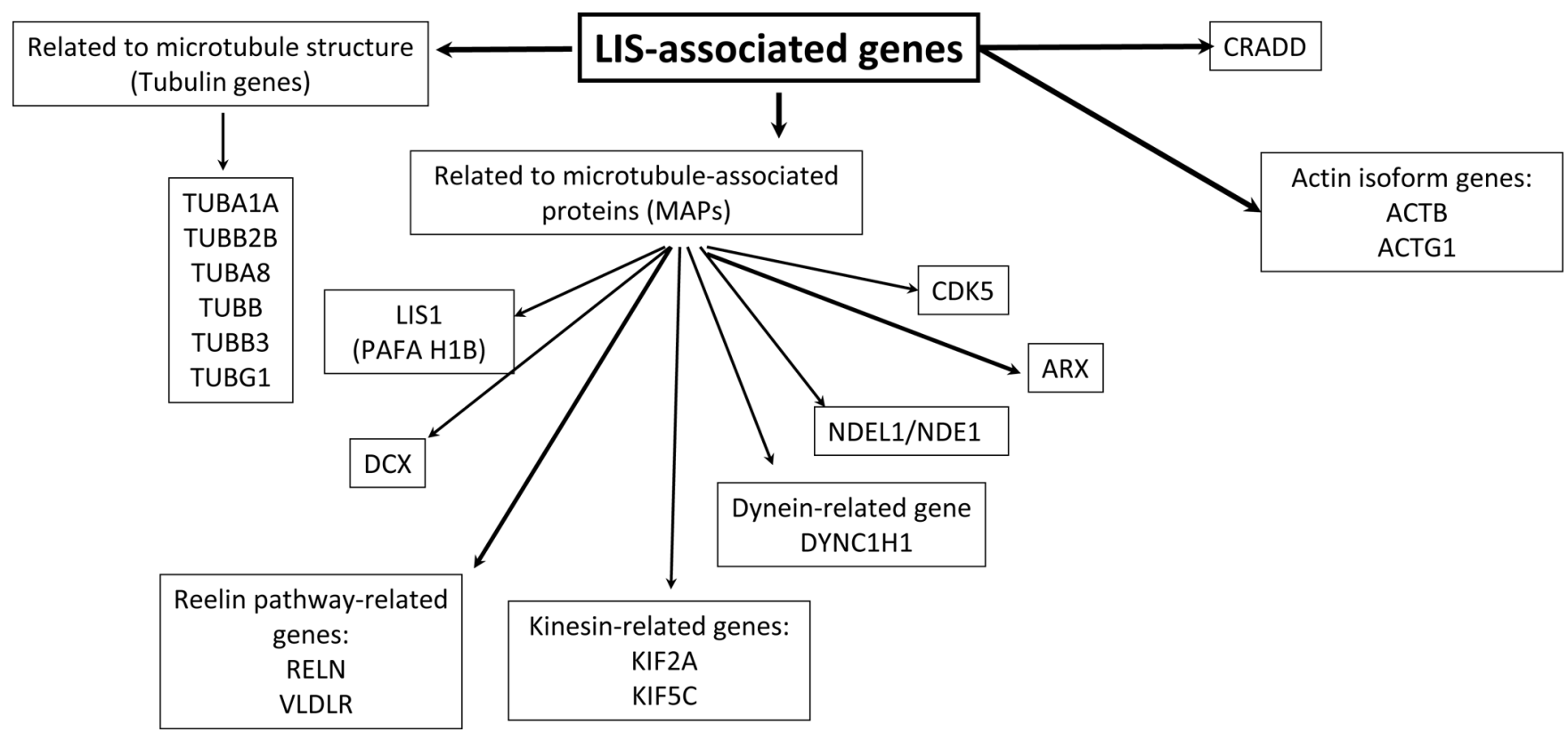

Figure 1 Lissencephaly (LIS)-associated genes, many of which are related to microtubule structural proteins (tubulin) or microtubuleassociated proteins (MAPs).

ambiguous genitalia is highly suggestive of $A R X$ mutation. If LIS is seen in association with macrocephaly, genetic testing for $C R A D D$ mutations should be considered. Several imaging features may help to narrow down the underlying genetic abnormality of LIS. These include the radiological characterization of LIS (gradient of gyral malformation and type of LIS) and associated extra-cortical findings such as malformations involving the cerebellum, basal ganglia and brainstem, as well as the presence of periventricular calcifications, ventriculomegaly and white matter signal abnormalities (Figure 2).

\section{LIS associated-genes and their function in neuronal migration}

Neuronal migration is a complex process which requires precise coordination between many gene products. Majority of LIS-related genes are related to microtubule structural proteins (tubulin) or MAPs. Their roles in association with neuronal migration are delineated in Figure 3.

\section{LIS1 gene}

LIS1-associated LIS includes isolated LIS syndrome (ILS), MDS and rarely subcortical band heterotopia $(\mathrm{SBH})$.
Patients with LIS1-associated LIS are characterized by drug-resistant epilepsy (16). While heterozygous deletions or intragenic mutations in LIS1 lead to ILS, variable micro deletions of chromosome 17p.13.3 including the LIS1 and YWHAE genes cause MDS (17). In 2013, Classen et al. (18) reported a novel inverted microduplication of chromosome 17 p13.3 in a child with pachygyria, profound intellectual impairment, and facial dysmorphism. Profound LIS with diffuse agyria and facial dysmorphism are features of MDS (17). YWHAE is crucial in the process of neuronal migration (19). Its interaction with NDEL1 (NUDEL) and dynein is also indispensable in the regulation of microtubule function (19). Isolated deletion of $Y W H A E$ leads to facial dysmorphism, growth retardation and structural intracranial abnormalities, including neuronal migration disorders and severe corpus callosal hypoplasia $(20,21)$.

Approximately $60 \%$ of patients with posterior predominant classical LIS have genomic alterations of LIS1 (22) (Figure 4). A posterior-predominant simplified gyral pattern with underlying $\mathrm{SBH}$ has also been associated with mosaic mutations of LIS1 (23) (Figure 5). LIS1-associated SBH has also rarely been associated with germline or somatic intragenic LIS1 pathogenic variants and, in contrast to $D C X$-related $\mathrm{SBH}$, it typically presents with posterior predominant SBH (24-26). Mild 


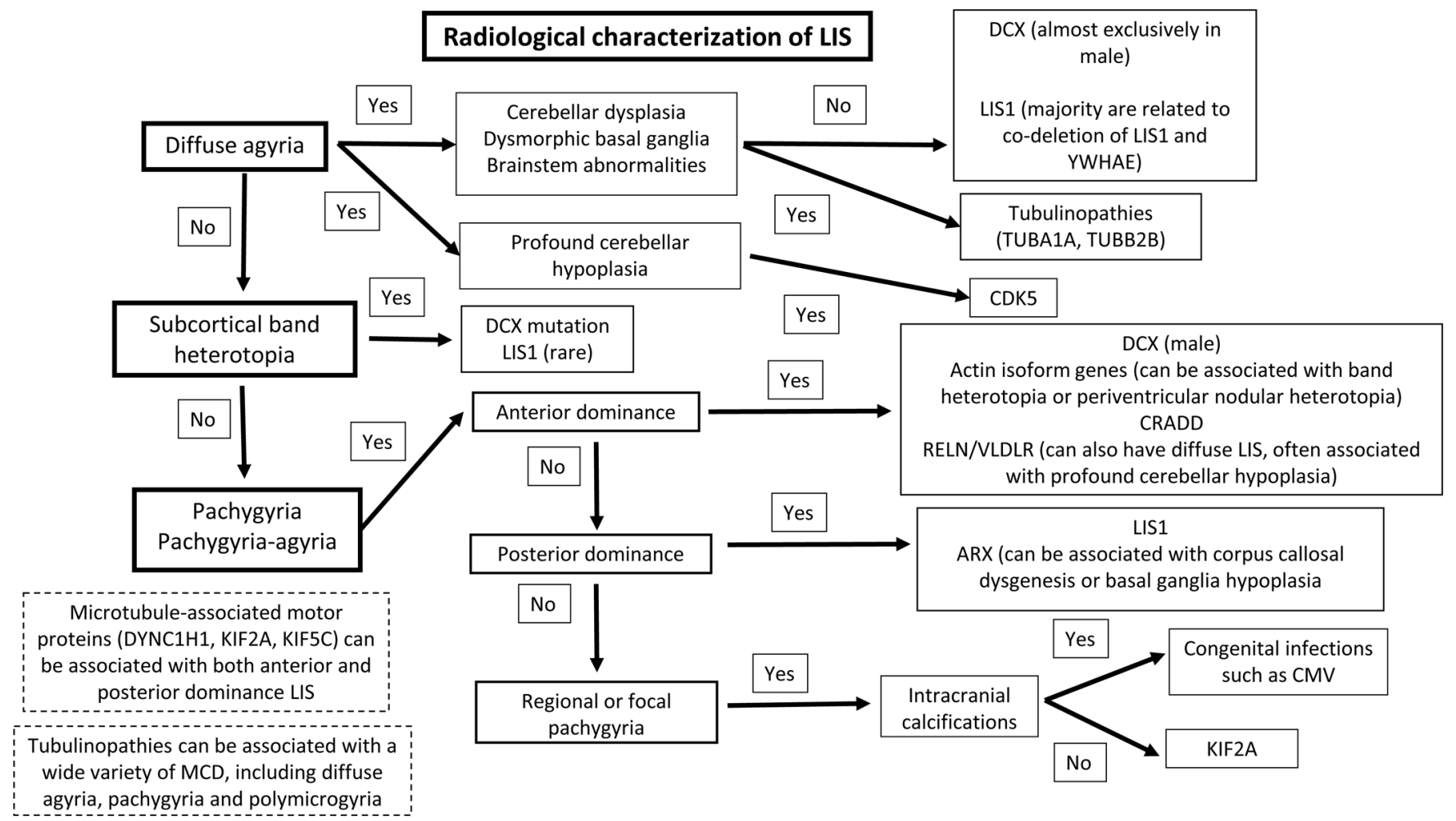

Figure 2 Radiological characterisation of LIS. Cerebellar hypoplasia/dysplasia, dysmorphic basal ganglia, thin or absent corpus callosum, ventricular dilation, and abnormalities of the hippocampus and brainstem are useful diagnostic indicators of tubulin gene involvement. Severe cerebellar/brainstem hypoplasia is also seen in association with RELN/VLDLR and NDE1 mutations. In the presence of intracranial calcifications and ventriculomegaly, congenital CMV/TORCH infection needs to be excluded. LIS, lissencephaly.

ventriculomegaly, prominent perivascular spaces as well as mild hypoplasia of the corpus callosum and vermis are other reported neuro-radiological findings $(27,28)$.

Although germline mosaicism in a parent could lead to familial recurrence, all LIS1 pathogenic variants reported to date have been de novo (29). Neither the mutation type nor the location of the mutation was found to predict the severity of LIS (28).

\section{Doublecortin (DCX) gene on chromosome Xq23}

Stabilization and polymerization of microtubules are highly dependent on the $D C X$ gene (30). The binding of the DCX protein to the microtubule skeleton facilitates the formation of the leading process of the migrating neuron (31).

$D C X$-related disorders include classical LIS, usually in males; and SBH, primarily in females. Mutations in $D C X$ have been found in $80 \%$ of sporadic females and $25 \%$ of sporadic males with SBH (32). Most cases of familial SBH are result of $D C X$ mutations. Somatic or germline mosaicism was found in approximately $10 \%$ of unaffected mothers of children with $D C X$-related LIS $(33,34)$ while the risk of transmission in a female who is heterozygous for a $D C X$ pathogenic variant is approximately $50 \%$ in each pregnancy (35).

Unlike LIS1-related classical LIS, DCX-related classical LIS demonstrates an anterior predominance or may be diffuse. $D C X$-related SBH is also predominantly located in the fronto-parietal lobe. A more severe malformation that overlaps with classic LIS and SBH, is characterized by $\mathrm{SBH}$ in the occipital regions and pachygyria in the frontal regions, also seen in LIS associated with mutations of actin isoform genes. Other neuroimaging features described in patents with $D C X$-related LIS include prominent perivascular spaces, delayed myelination as well as ventriculomegaly (35). $D C X$-related LIS was not previously known to be associated with cerebellar hypoplasia or corpus 


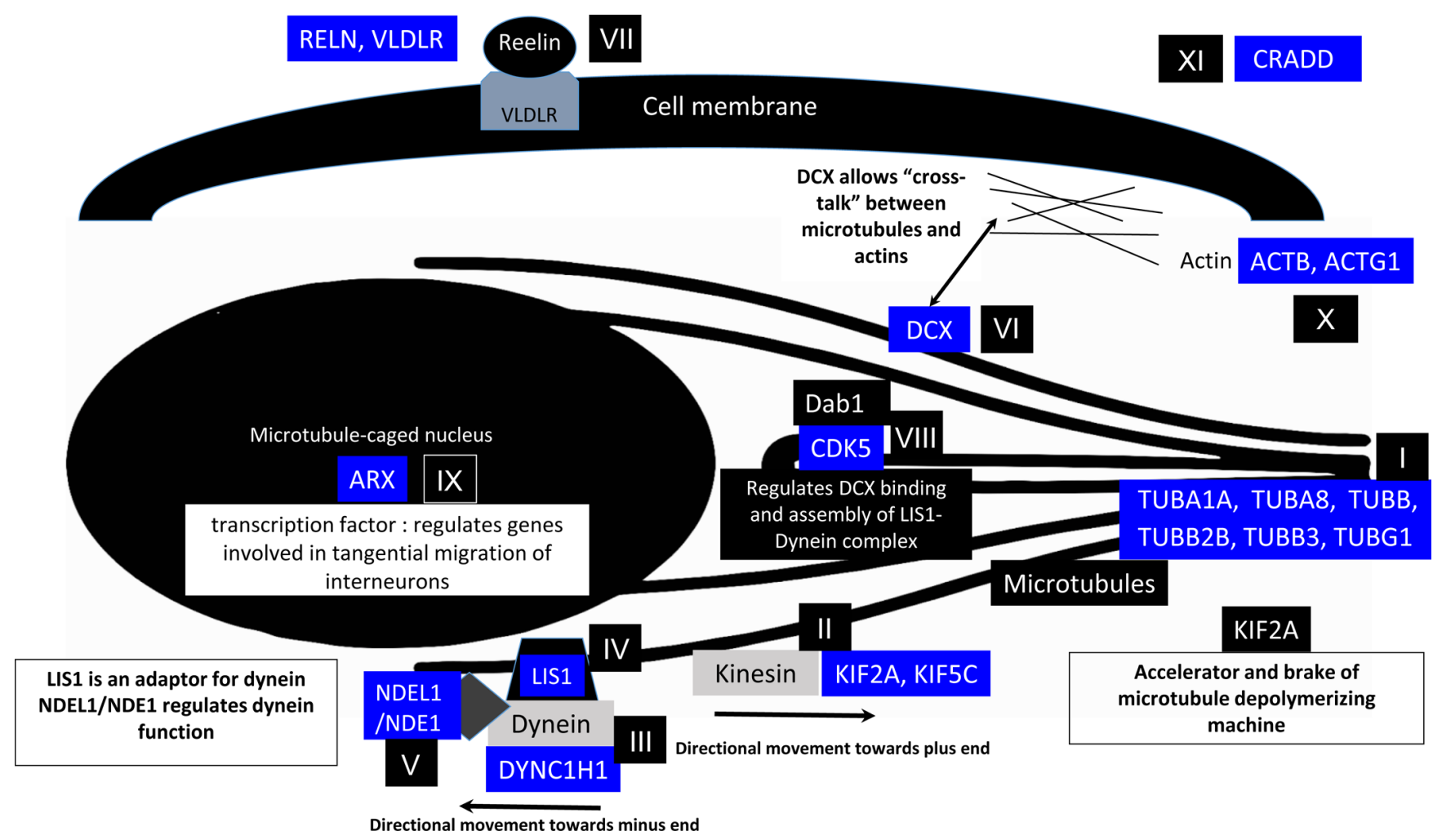

Figure 3 Roles of LIS-associated genes in association with microtubule function and neuronal migration/organization. (I) Mutations in tubulin isotypes disrupt the formation of normal heterodimers of $\alpha$ - and $\beta$-tubulin polypeptides, affecting the structural stability and function of microtubules; (II) kinesins and (III) dyneins are microtubule motor proteins that power directional movement along microtubules. Lissencephaly (LIS)-related genes that encode these motor proteins include KIF2A, KIF5C and DYNC1H1; (IV) the LIS1 gene encodes the LIS1 protein which is an adaptor for the microtubule-motor dynein that allows dynein to remain attached to microtubules for longer periods of time; (V) the mammalian NudE homologues (NDE1 and NDEL1) are required for the targeting of LIS1 to the dynein complex. It also releases the blocking effect of LIS1 on cytoplasmic dynein; (VI) DCX protein binds directly to microtubules to stabilize and promote polymerization, facilitates the formation of the microtubule cage around the nucleus, as well as stabilizes microtubules in the leading process of the migrating neuron; (VII) the Reelin signalling pathway aids in the regulation of neuronal migration and positioning, generating the "inside first-outside last" configuration of the 6-layer cortex; (VIII) CDK5 regulates the binding and assembly of LIS1-dynein complex as well as the direct binding of DCX to microtubules; (IX) the ARX gene encodes the ARX protein (a transcription factor) which regulates genes that play crucial roles in tangential migration of GABAergic interneurons into the cortical plate; (X) ACTB and ACTG1 encode $\beta$ and $\gamma$-actin. The interaction between microtubules and cytoplasmic actin plays an important role in neuronal migration. DCX protein allows "cross-talk" between microtubules and cytoplasmic actins; (XI) the CRADD gene is a recently discovered LIS-associated gene. Its role in neuronal migration and hence development of LIS is still unclear and needs further investigation. MCD, malformations of cortical development.

callosal dysgenesis (36). Severe hypoplasia of the corpus callosum was however observed in one of our patients with anterior predominant classical LIS (Figure 6). Mild hypoplasia of the posterior corpus callosum was also noted in another patient with $D C X$-related SBH (Figure 7). The extent of cortical abnormalities, band thickness and ventricular enlargement are factors that predict the clinical severity of SBH $(37,38)$.

Molecular genetic testing for DCX mutations should be considered in the presence of SBH, generalised or frontal predominant LIS, especially in the context of a family history compatible with $\mathrm{X}$-linked inheritance. 

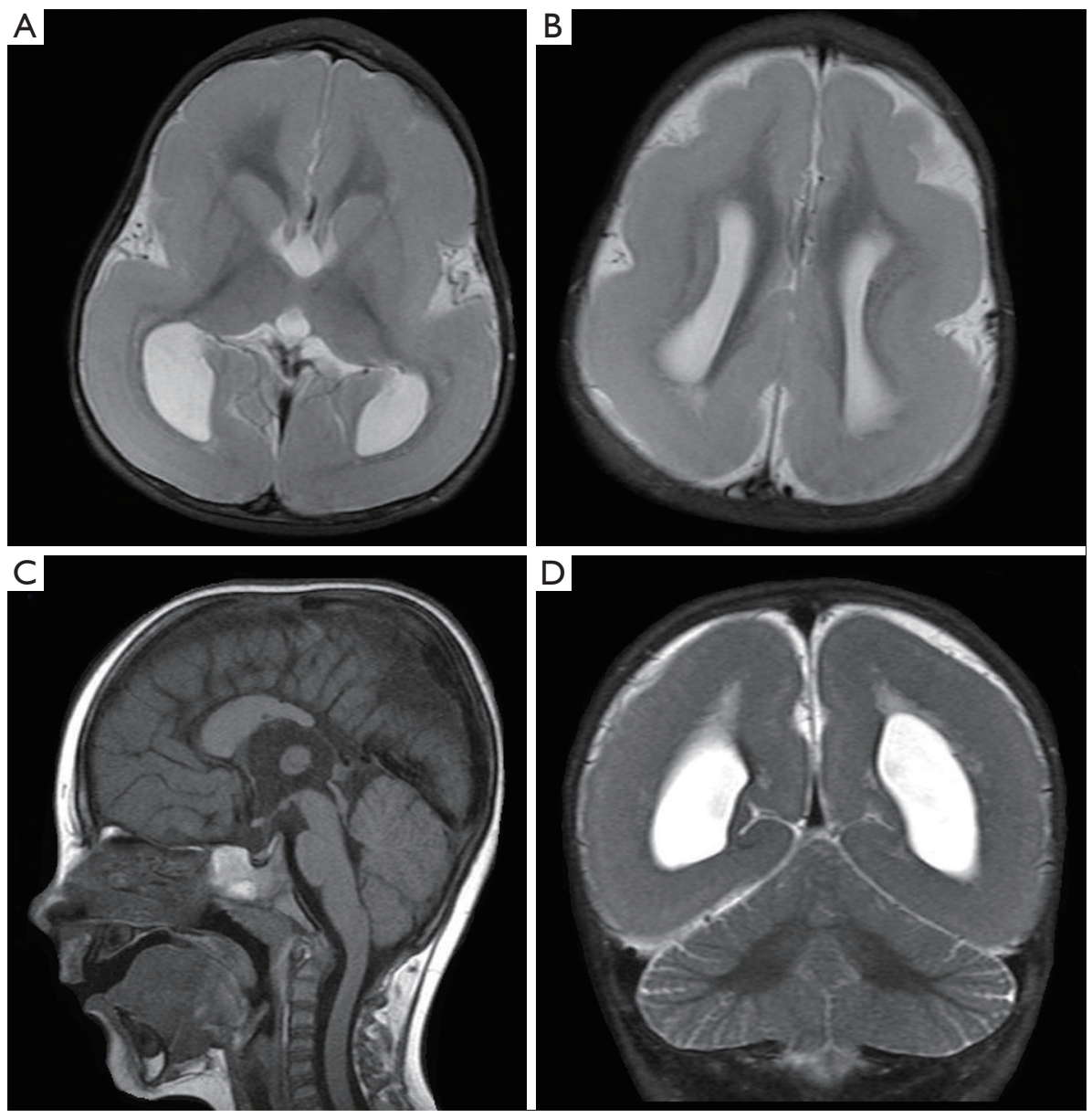

Figure 4 Classical lissencephaly in a patient with heterozygous deletion in the LIS1 gene. (A,B) Axial T2-weighted images demonstrate the presence of posterior predominant LIS with a thick cortex. Mild ventriculomegaly is noted; (C) sagittal T1-weighted and (D) coronal T2weighted images show normal appearances of the cerebellum and brainstem. Partial agenesis of the corpus callosum is also noted.

\section{Tubulin genes}

Microtubules are made up of alternating $\alpha$ - and $\beta$-tubulin polypeptides which bind to a $\gamma$-tubulin ring complex $(39,40)$. The production of motion along microtubules is determined by a wide spectrum of MAPs. Mutations in several tubulin isotypes have been associated with various developmental brain anomalies involving the basal ganglia, cerebral cortical grey matter, commissural tracts, cerebellum and brainstem (an expression of neuronal migration and axonal guidance disorders) $(39,41)$. Mutations in several tubulin isotypes have also been associated with hypoplastic olfactory nerves (42), diminished overall white matter volume and small, asymmetric brainstem $(15,39)$, believed to be related to disturbances in axonal pathfinding.
TUBA1A was the first tubulin isotype to be associated with brain malformations (43) and it is the most commonly mutated tubulin gene. TUBA1A is highly expressed in the embryonic brain, providing more than $95 \%$ of the $\alpha$-tubulin in the developing brain $(44,45)$. Mutations to TUBA1A could lead to a wide variety of MCD (39,41,46-49), the core imaging phenotype of which comprise of classic LIS with or without cerebellar hypoplasia (39). In 2015, Myers et al. reported the presence of microphthalmia and congenital cataract in a patient with TUBA1A mutation (50). Congenital cataract was also seen in one of our patients with TUBA1A mutation (Figure 8). As the brain and eye are derived from the ectoderm, the cooccurrence of developmental anomalies of these organs is not surprising. In addition, TUBA1A is expressed in both the fetal brain (43) and retina (51). TUBA1A mutations 

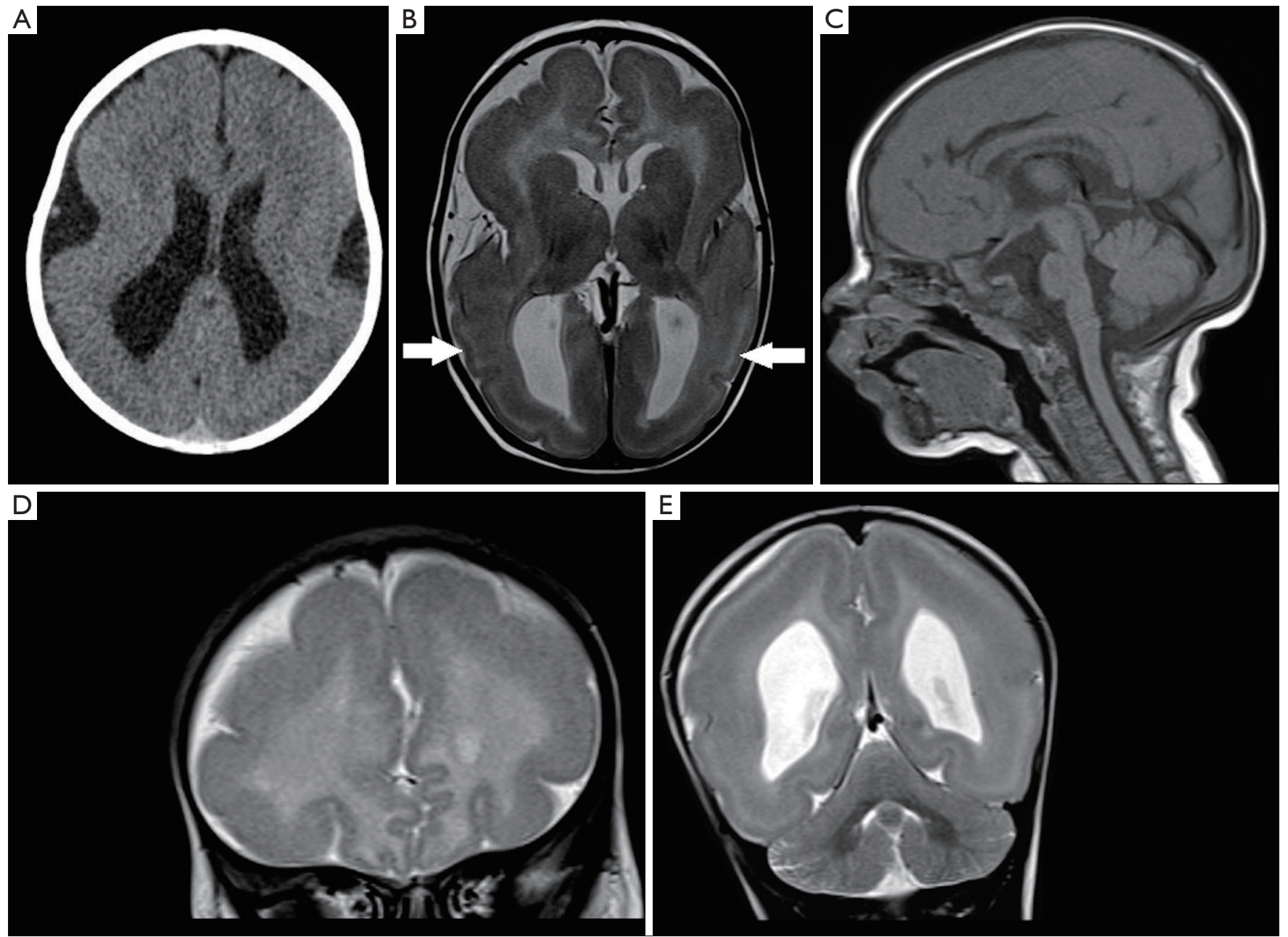

Figure 5 Posterior predominant pachygyria with underlying SBH in a patient with mosaic mutations of LIS1. (A) Axial CT image shows bilateral pachygyria with mild ventriculomegaly; (B) axial T2-weighted and (D,E) coronal T2-weighted images demonstrate the presence of bilateral pachygyria, more severe posteriorly. An underlying band of heterotopic grey matter (white arrows) is also present posteriorly; (C) sagittal T1-weighted image shows normal appearances of the cerebellum, brainstem and corpus callosum. SBH, subcortical band heterotopia.

have also been described in association with asymmetrical perisylvian polymicrogyria (PMG) (46,52,53), PMG-like cortical dysplasia (54) and microlissencephaly in foetal cases (49). Almost all reported cases of TUBA1A-related LIS exhibit some form of corpus callosal abnormalities, ranging from mild hypoplasia or dysmorphism to complete agenesis (55).

Mutations in several $\beta$-tubulin isotypes result in microlissencephaly, pachygyria (Figure 9), SBH and PMG. Schizencephaly (SCH), axonal dysinnervation and congenital fibrosis of extra-ocular muscles were also reported in patients with $T U B B 2 B$ mutations (56-58).
Focal PMG associated with localized band heterotopia was also reported in a patient with $T U B B$ mutation (59) while mutations in the TUBG1 gene were identified in individuals with posterior predominant pachygyria (15).

Recently, Romaniello et al. proposed a term "tubulinrelated cerebellar dysplasia" defined by the following characteristics: (I) consistent involvement of the hemispheres; (II) prevalent unilateral hemispheric involvement, predominantly in the supero-posterior aspect; (III) abnormal orientation of the cerebellar folia without cysts, cerebellar folial thickening or signal abnormalities. Interestingly, two of our patients with TUBA1A mutations 

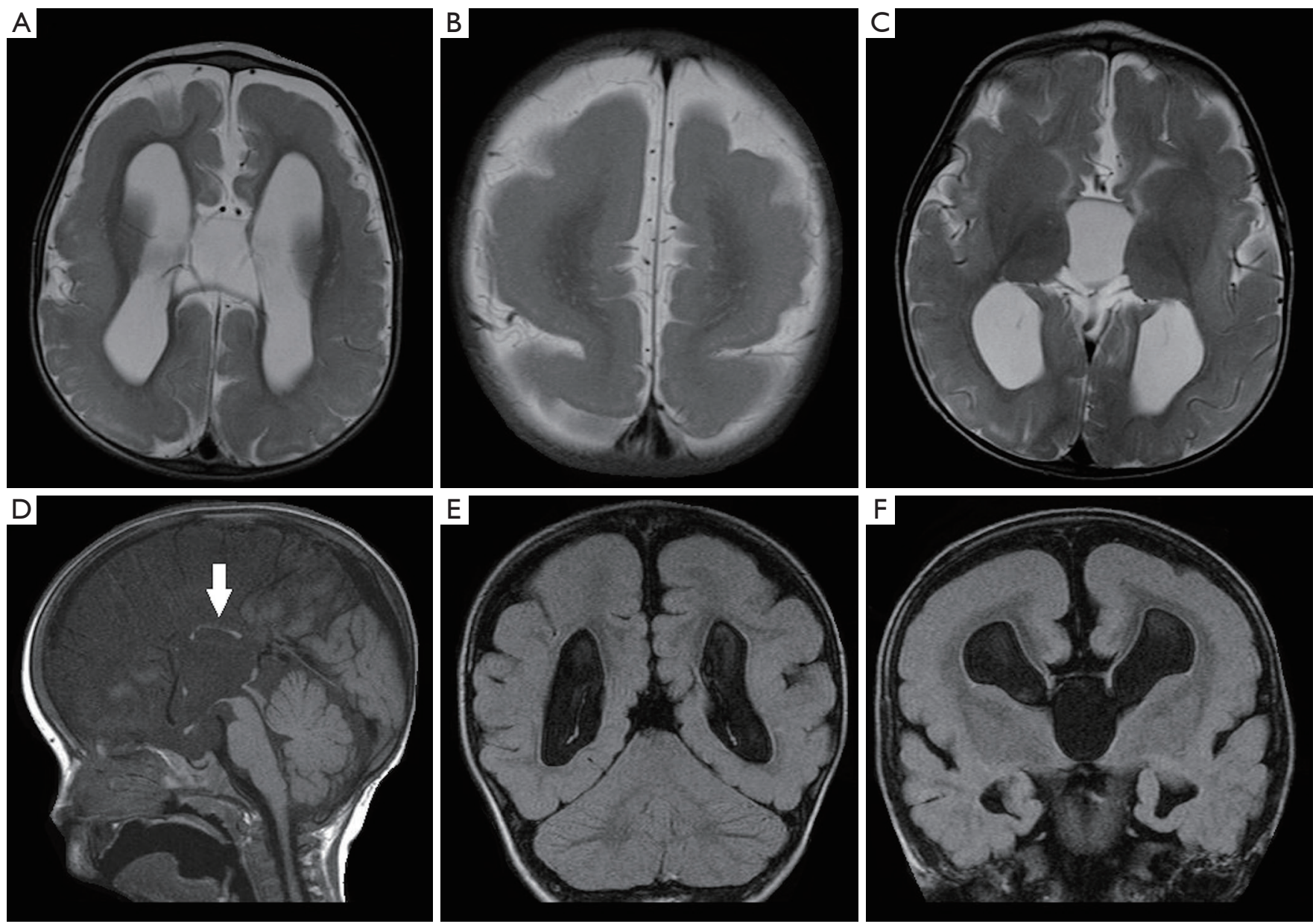

Figure 6 DCX-related lissencephaly due to a missense mutation. (A-C) Axial T2-weighted images show bilateral pachygyria with thick cortex (involving predominantly the frontoparietal lobes) and moderate ventriculomegaly. The basal ganglia is normal in appearance; (D) sagittal T1-weighted image shows severe hypoplasia of the corpus callosum (white arrow). The brainstem and vermis are normal; (E,F) coronal FLAIR images confirms the presence of morphologically normal cerebellar hemispheres and abnormal orientation of the hippocampi.

have tiny cerebellar cysts (Figures 8,10).

\section{Aristaless-related homeobox (ARX)}

$\mathrm{X}$-linked LIS with abnormal genitalia (XLAG) is a result of $A R X$ gene mutations. Gene product of the $A R X$ gene plays crucial roles in neuronal proliferation, interneuronal migration, embryonic forebrain differentiation as well as testicular development (14). $A R X$ mutations were described for the first time by Kitamura et al. in 2002 (14). Till date, at least 30 mutations involving the $A R X$ gene have been associated with XLAG.

XLAG is believed to be primarily related to defects in tangential migration of GABAergic interneurons (60). In 2005, Kato and Dobyns coined the term "interneuronopathy" to describe this pathological condition (61).

Marked disproportion between inhibitory interneurons and excitatory projection neurons result in intractable seizures in patients with XLAG (62). Hydranencephaly, LIS and early-onset epileptic encephalopathies are among the many phenotypes of $A R X$ mutations (62-64). In the most severe form, profound autonomous nervous system disturbances may lead to severe morbidity or even mortality (60). Females with an $A R X$ gene mutation typically exhibit a less severe phenotype. Disruption of ARX protein function in the pancreas results in chronic diarrhea, 

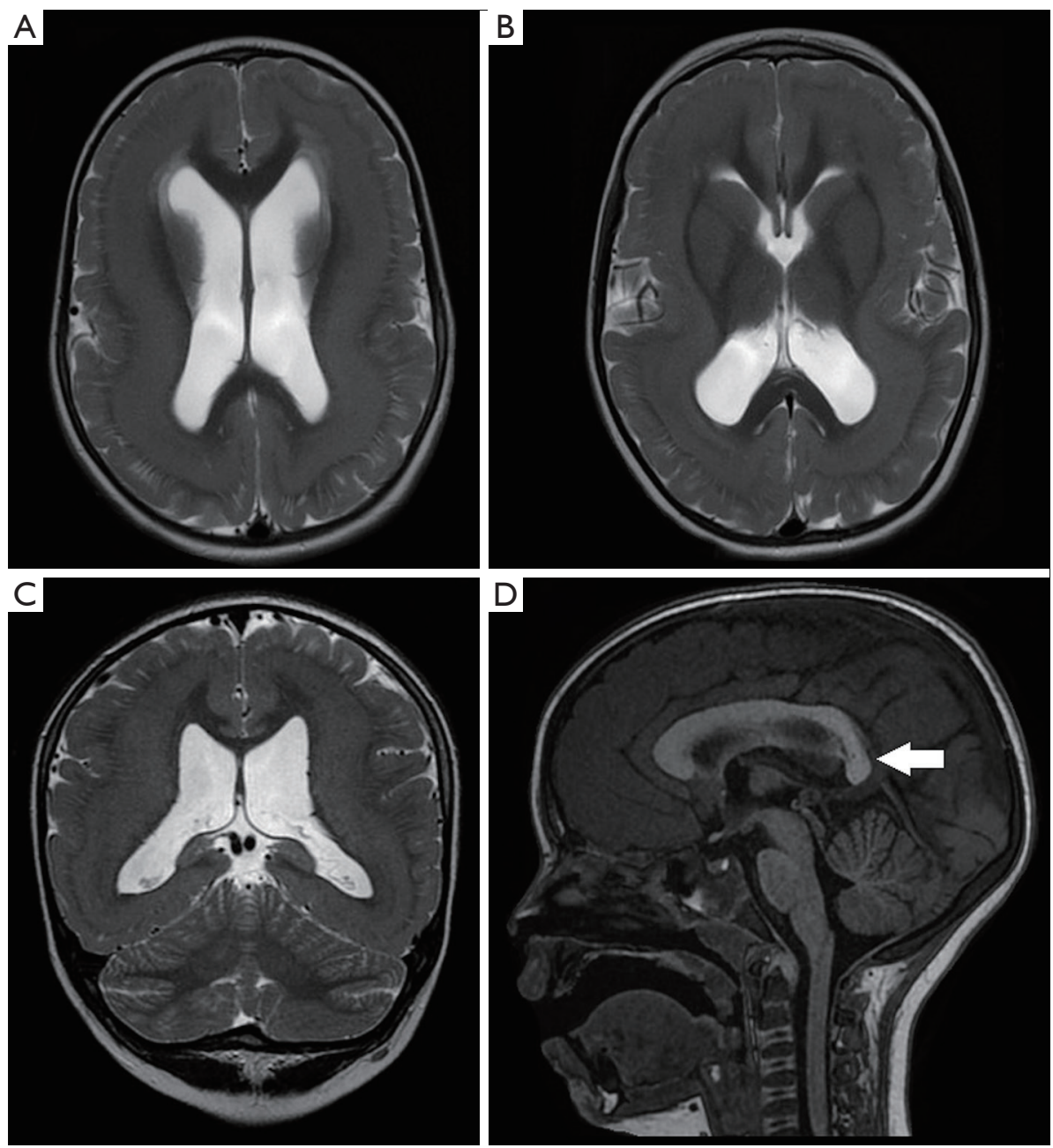

Figure 7 DCX-related SBH in a female patient. (A,B) Axial and (C) coronal T2-weighted images show bilateral SBH with ventriculomegaly and prominent perivascular spaces. The basal ganglia and cerebellum are normal; (D) sagittal T1-weighted image shows mild hypoplasia of the posterior corpus callosum with loss of the normal bulbous appearance of the splenium (white arrow). SBH, subcortical band heterotopia.

experienced by individuals with XLAG.

Posterior predominant LIS (especially anterior pachygyria and posterior agyria) with moderately increased cortical thickness, corpus callosal dysgenesis, striatal and thalamic nuclei atrophy are features described in association with XLAG (Figure 11).

\section{Reelin patbway-related genes (RELN, VLDLR)}

The RELN gene was first linked to cortical development by the observation of disorganized cerebral and cerebellar cortices in reeler-mutant mice (65). In humans, reelin protein (the gene product of RELN gene) is found in the central nervous system, especially in the cerebellum (66).
Reelin plays a key role in the organization of architectonic patterns in the cerebral cortex. VLDLR is an essential cellsurface receptor for reelin (67).

Mutations in RELN (11) and VLDLR (67) have been associated with anterior predominant LIS, severe hippocampal and cerebellar hypoplasia/dysplasia. However, from the authors' experience, reelin pathway-related-LIS are more commonly associated with diffuse LIS. Both RELN and VLDLR mutations are associated with profound cerebellar hypoplasia/dysplasia. The first case of $V L D L R-$ related LIS with a strong cerebellar phenotype was reported in 2008 by Ozcelik et al. (68).

NRS is a rare form of microlissencephaly caused by a mutation in the RELN gene (11). It was first described 

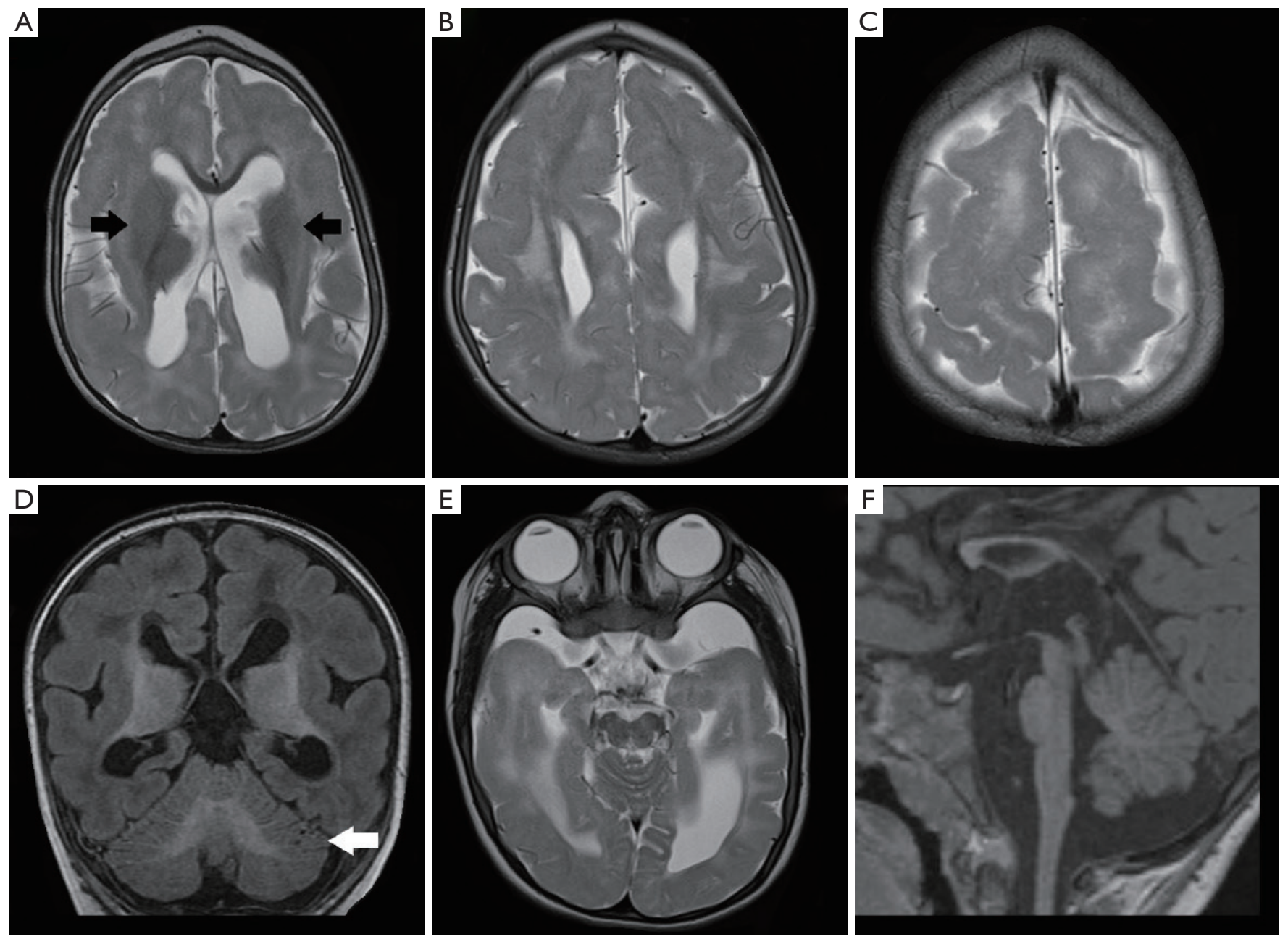

Figure 8 TUBA1A-related lissencephaly. (A-C) Axial T2-weighted images demonstrate bilateral perisylvian pachygyria-polymicrogyria with mild ventriculomegaly and signal abnormalities within the cerebral white matter. There is also absence of the anterior limb of the internal capsules with fusion of the caudate head and lentiform nucleus bilaterally (black arrow); (D) coronal T1-weighted image shows tiny cysts within the left cerebellar hemisphere (white arrow); (E) axial T2-weighted MRI image shows bilateral intra-ocular lens replacement due to congenital cataracts; (F) sagittal T1-weighted image shows partial agenesis of the corpus callosum and mild hypoplasia of the brainstem.

in two patients in 1976 by Norman et al. (69). In 2004, Caksen et al. reported two patients with NRS; one of the patients had atrial septal defect, corpus callosum agenesis and widespread intracranial calcifications while the other patient had bilateral macular cherry-red spot, persistent foramen ovale and cerebellar atrophy (70). In 2000, the autopsy findings of a male fetus with NRS was reported for the first time (71). Prenatal ultrasound at 25 weeks of gestation revealed extreme microcephaly and post-mortem examination after termination of pregnancy at 27 weeks of gestation revealed complete agyria and failure of operculization of the insula (71). Since its first description in 1976, all reported cases share several common features; microcephaly, LIS and distinctive craniofacial features.

\section{Cyclin-dependent kinase 5 (CDK5)}

CDK5, a member of the cyclin-dependent kinases family, has profound expression in post-mitotic neurons within the central nervous system (72). It is extensively involved in signalling pathways of neuronal migration and cortical layering (73). The CDK5 protein interacts with both 

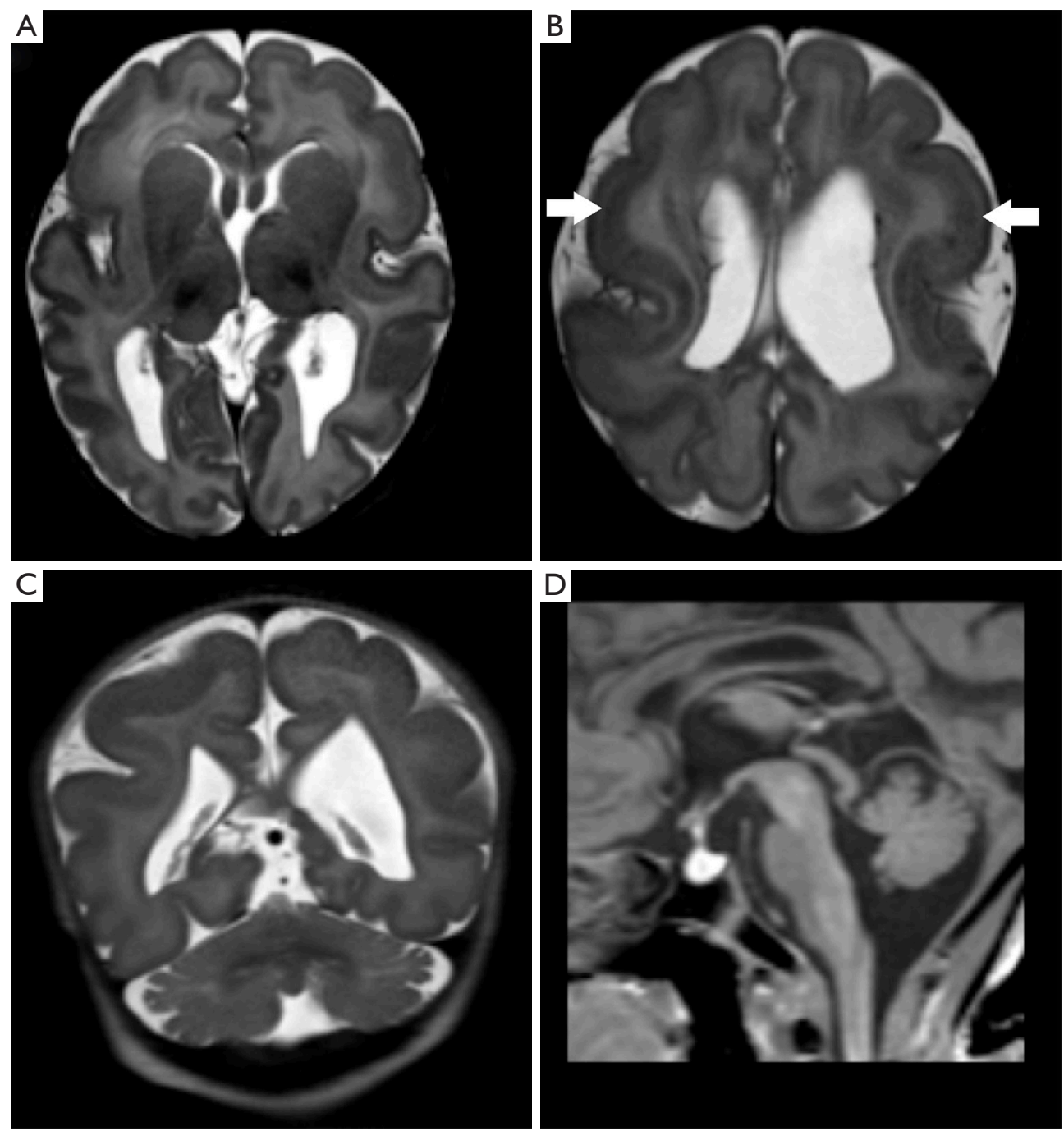

Figure 9 TUBB2B-related lissencephaly. (A,B) Axial T2-weighted images show anterior predominant pachygyria with thin cortex and underlying SBH (white arrows). There is also absence of the anterior limb of the internal capsule with fusion of the caudate head and lentiform nucleus bilaterally. The ventricles are asymmetrically enlarged; (C) coronal T2-weighted and (D) sagittal T1-weighted images show pontocerebellar hypoplasia as well as mild hypoplasia of the corpus callosum. SBH, subcortical band heterotopia.

DCX and LIS1 $(74,75)$. Binding of DCX to microtubule is regulated by CDK5 (75). Disruption of CDK5 function results in abnormal layering of cortical and cerebellar cortices in murine models (76-78). The CDK5-mutant mouse exhibits an inverted cortical lamination, similar to those seen in reeler mutant mice (79). This is not surprising as CDK5 is a downstream target of the reelin signalling pathway.

In 2015, Magen et al. discovered a novel homozygous splice site mutation in $C D K 5$ which gives rise to a lethal form of LIS with cerebellar hypoplasia (72). All affected patients showed severe LIS with complete agyria, severe cerebellar hypoplasia and corpus callosal dysgenesis (72). On histopathological examination, a combination of twolayer lamination (similar to that observed in TUBA1Aassociated LIS) and three-layer lamination (reminiscent of $A R X$-related LIS) was seen (80).

\section{Kinesin superfamily genes (KIF2A, KIF5C)}

Kinesin uses energy released from ATP hydrolysis to power directional progression along microtubule cytoskeleton, a crucial step in neuronal migration. They are also essential in 

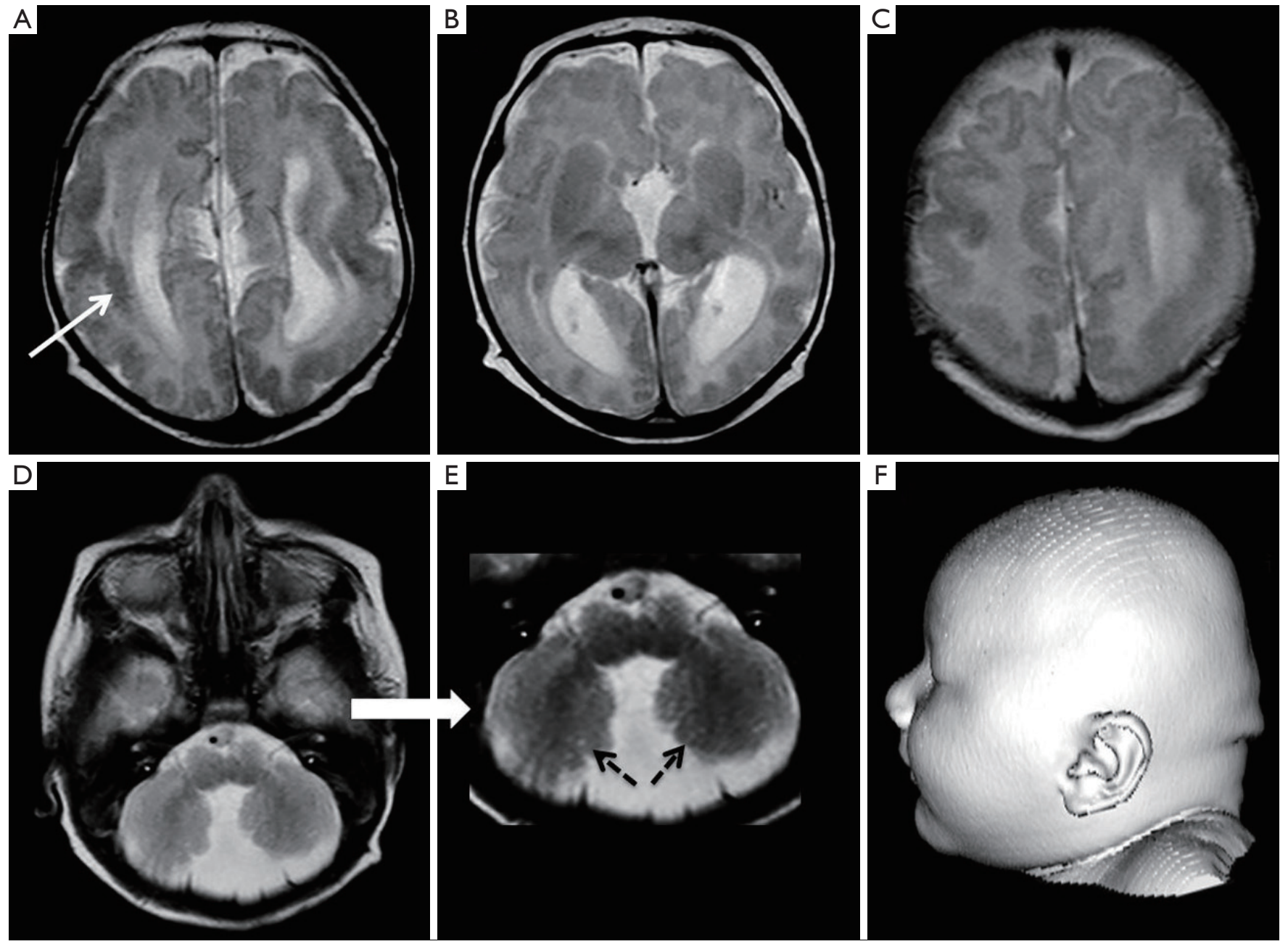

Figure 10 TUBA1A-related lissencephaly. (A-C) Axial T2-weighted images show bilateral central pachygyria-polymicrogyria with subcortical band of heterotopic grey matter (thin white arrow in A). There is also fusion of the caudate head and lentiform nucleus bilaterally due to absence of the anterior limb of the internal capsules. Complete corpus callosal agenesis is noted with colpocephaly; (D,E) axial T2weighted image across the posterior fossa shows hypoplasia and abnormal shape of the pons. The cerebellar vermis is deficient with dysplasia of the cerebellar hemispheres and the presence of tiny cerebellar hemispheric cysts (black arrows in E); (F) 3D CT image shows severe microcephaly.

neuronal proliferation and post-migrational development. Recently, kinesin superfamily proteins were also found to play an important role as microtubule stabilizers and depolymerizers (81).

There are limited reports on kinesin-related LIS in the literature (15,82-85). Thus far, four patients with posterior predominant LIS, normal posterior fossa structures and variable degree of microcephaly were reported to harbour mutations of KIF $2 A$ gene involving the Ser 317 and His 321 residues (postulated mutation hotspots) $(15,86)$. This pattern of LIS is similar to that related to LIS1 gene. One of the reported patients also has hypoplasia of the corpus callosum (15). All four reported patients have spastic tetraplegia and three out of the four patients have visual symptoms (cortical blindness and nystagmus) (86). KIF $2 A$ null mice were found to have multiple brain abnormalities, including cortical lamination defects (87).

The KIF5C gene was recently established as a rare genetic cause of regional or focal pachygyria. Microcephaly may also be present. Thus far, only six cases were reported $(15,84,85,88,89)$. Pathogenic variants of KIFSC produce kinesin proteins that are incapable of hydrolyzing ATP, 

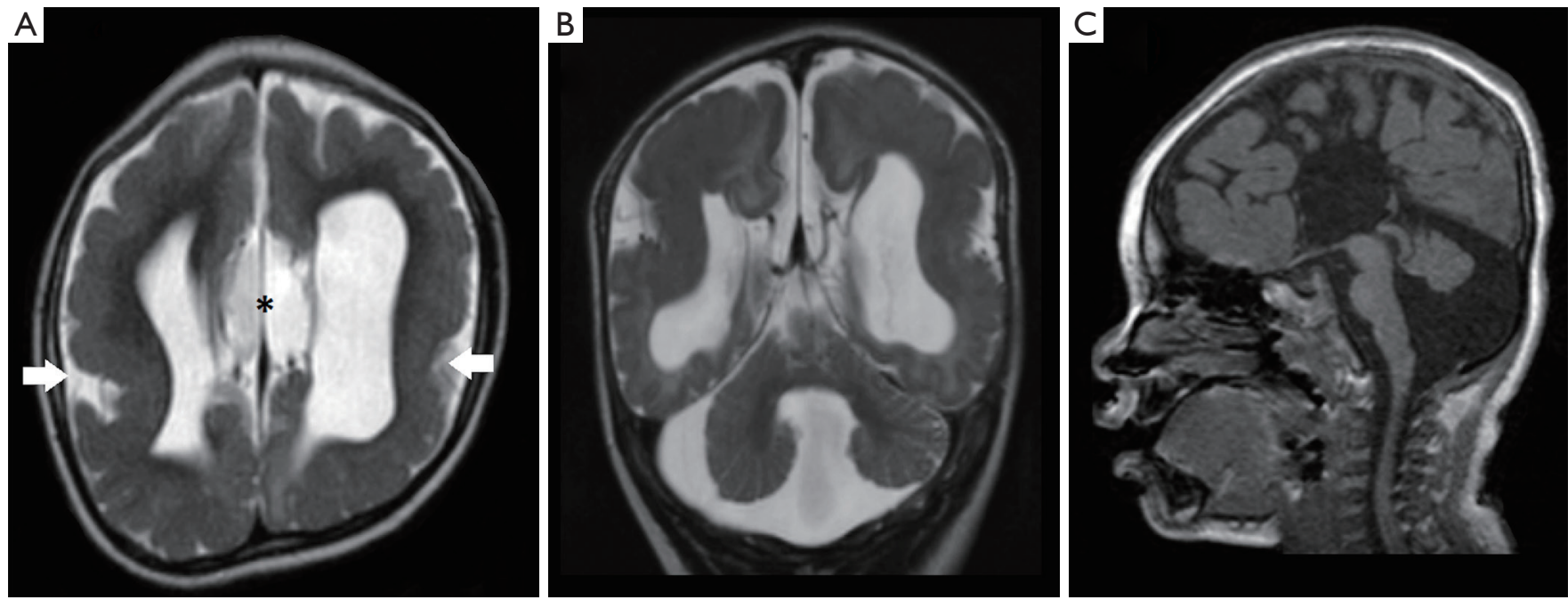

Figure $11 \mathrm{X}$-linked lissencephaly with abnormal genitalia (XLAG). This child presented with intractable seizures soon after birth and was noted to have micropenis and bilateral undescended testis on examination. (A) Axial T2-weighted; (B) coronal T2-weighted and (C) sagittal T1-weighted images show a simplified gyral pattern and perisylvian pachygyria (white arrows in A), along with hypoplasia of the brainstem, vermis and cerebellar hemispheres. There is complete agenesis of the corpus callosum with an interhemispheric cyst $\left({ }^{*}\right)$. Of note is also the presence of microcephaly.

resulting in failure of energy production crucial for directional movement along microtubules (90). Imaging revealed the presence of subtle LIS in all patients with a distinctive frontal distribution in five out of six patients (89). Only one reported patient had a posterior predominant LIS (88). Other reported MRI findings include mild ventriculomegaly and corpus callosal dysgenesis.

\section{DYNC1H1 gene}

Mutations in DYNC1H1 have been associated with posteriorpredominant pachygyria, PMG, nodular heterotopia, hypoplasia of the corpus callosum, microcephaly and basal ganglia malformation, as well as peripheral neuropathy (15).

Missense mutations in DYNC1H1 have been reported in association with Charcot-Marie-Tooth disease (91) and spinal muscular atrophy $(92,93)$. More recently, de novo missense mutations were reported in two individuals with intellectual disability and cortical malformations $(93,94)$.

\section{NudE bomologues (NDE1, NDEL1)}

LIS1 and its binding protein (NudE homologues) were found to have essential roles in the regulation of cytoplasmic dynein function and localization $(95,96)$. They also play crucial roles in microtubule regulation and determination of cell polarity (97).

Mutations of NDE1 result in severe microcephaly with a simplified gyral pattern, agenesis of the corpus callosum, and cerebellar hypoplasia $(98,99)$. In 2011, Bakircioglu et al. identified 2 different homozygous truncating mutations in the NDE1 gene in affected members of 3 consanguineous families with LIS and extreme microcephaly (99). In the same year, Alkuraya et al. independently identified 2 homozygous truncating mutations in the NDE1 gene in affected members from 2 consanguineous Saudi Arabian families with LIS (98). In two related Turkish patients with microhydranencephaly, hypoplasia of the corpus callosum, cerebellum and brainstem hypoplasia, Guven et al. identified a homozygous intragenic deletion in the NDE1 gene (100). Both patients had extreme microcephaly, profound motor and mental retardation.

\section{CRADD gene}

The $C R A D D$ gene encodes a protein which is essential for activation of caspase-2-mediated programmed cell death (101). In 2016, Di Donato et al. reported six cases of mild "thin" LIS (TLIS) variant with megalencephaly and intellectual disability due to loss of CRADD function (10). The constellation of findings in these patients suggested reduced apoptosis as an important pathomechanism which 

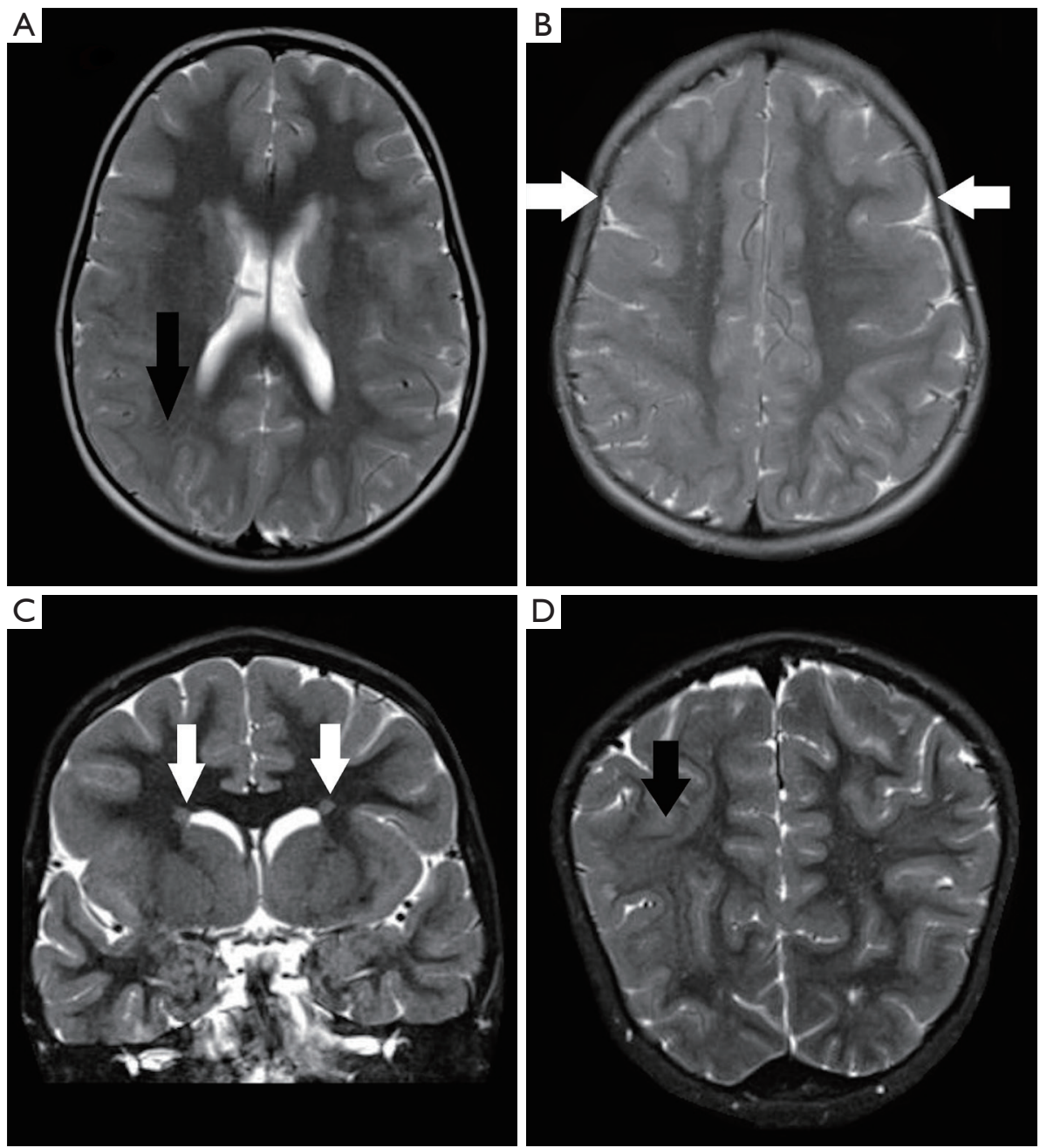

Figure 12 Actin-isoform gene-related lissencephaly. (A,B) Axial T2-weighted and (C,D) coronal T2-weighted images show subtle anterior pachygyria/simplified gyral pattern (white arrows in B) with posterior SBH (black arrows in A and D). Bilateral frontal periventricular nodular heterotopia (white arrows in $\mathrm{C}$ ) is also observed. SBH, subcortical band heterotopia.

underlies the observed cortical malformation. The role of CRADD/caspase-2 signalling in cortical development needs further investigation and may be related to reduced synaptic elimination and decreased neuronal apoptosis.

\section{Actin isoform genes (ACTB, ACTG1)}

$A C T B$ and $A C T G 1$ encode $\beta$ - and $\gamma$-actin respectively, two of the six actin isoforms widely expressed in non-muscle cytoplasmic actin. In addition to microtubules, the actin cytoskeleton is also important for neuronal migration $(102,103)$. Disruption of the actin cytoskeleton likely interferes with the shape alteration and leading process function during neuronal migration.

Anterior predominant pachygyria is seen in majority of patients with $A C T B$ and $A C T G 1$ mutations, reminiscent to that seen in male patients with pathogenic variants of $D C X$ gene $(104,105)$. SBH or periventricular heterotopia may also be present $(105,106)$ (Figures 12,13). The lateral ventricles may be mildly prominent but the hindbrain is usually normal. The corpus callosum may be absent or appear short and thick (107). Recently, Di Donato et al. reported seven patients with ACTG1 mutations. Four of these patients exhibited a highly similar imaging phenotype, characterised by frontal predominant pachygyria merging with posterior predominant band heterotopia. MRI brain of two other patients showed 

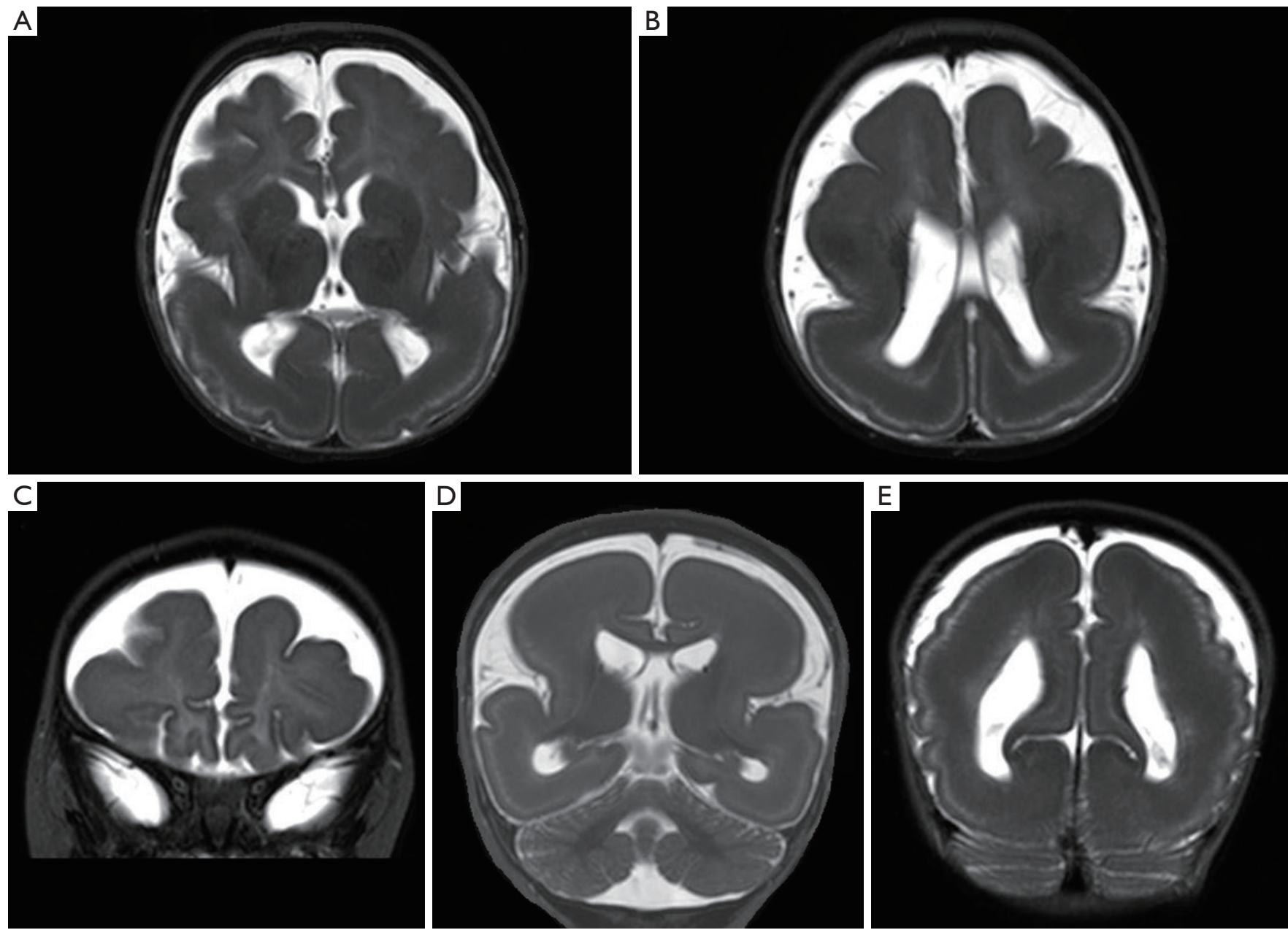

Figure 13 Actin-isoform gene-related LIS. (A,B) Axial T2-weighted and (C-E) coronal T2-weighted images demonstrate frontal predominant pachygyria merging with posterior subcortical band heterotopia. Mild ventriculomegaly is also noted. The cerebellar hemispheres are normal. LIS, lissencephaly.

bilaterally simplified gyration in the frontal lobes (108).

Gain-of-function missense mutations in $A C T B$ and $A C T G 1$ genes are associated with BWS (109). BWS is characterized by typical craniofacial features and intellectual disability. Typical craniofacial features were reported to be more prominent in patients with ACTB-associated BWS, while LIS is more common in patients with ACTG1-associated BWS (108). Genetic testing for ACTB and ACTG1 mutations should be carried out in patients with anterior predominant LIS but do not harbour DCX mutations.

\section{Conclusions}

Mechanisms underlying LIS map onto molecular processes/ pathways and are interdependent on one another, explaining the wide array of clinical and imaging phenotypes. The continuous advancement in the field of molecular genetics in the last decade has led to identification of at least 19 LISrelated genes, most of which are related to microtubule structural proteins (tubulin) or MAPs. We have brought together current knowledge of gene mutations associated with LIS in an attempt to provide a comprehensive genotype-phenotype correlation. This is crucial to facilitate a more targeted genetic testing in patients with LIS. Identification of an underlying genetic etiology could have important implications for the affected individual and their family. Greater understanding of the genetic basis and molecular pathways associated with LIS may also lead to 
advances in diagnosis and treatment.

\section{Acknowledgements}

None.

\section{Footnote}

Conflicts of Interest: The authors have no conflicts of interest to declare.

\section{References}

1. des Portes V, Francis F, Pinard JM, Desguerre I, Moutard ML, Snoeck I, Meiners LC, Capron F, Cusmai R, Ricci S, Motte J, Echenne B, Ponsot G, Dulac O, Chelly J, Beldjord C. Doublecortin is the major gene causing $\mathrm{X}$-linked subcortical laminar heterotopia (SCLH). Hum Mol Genet 1998;7:1063-70.

2. Gleeson JG, Allen KM, Fox JW, Lamperti ED, Berkovic S, Scheffer I, Cooper EC, Dobyns WB, Minnerath SR, Ross ME, Walsh CA. Doublecortin, a brain-specific gene mutated in human X-linked lissencephaly and double cortex syndrome, encodes a putative signaling protein. Cell 1998;92:63-72.

3. Reiner O, Carrozzo R, Shen Y, Wehnert M, Faustinella F, Dobyns WB, Caskey CT, Ledbetter DH. Isolation of a Miller-Dieker lissencephaly gene containing $G$ protein beta-subunit-like repeats. Nature 1993;364:717-21.

4. Di Donato N, Chiari S, Mirzaa GM, Aldinger K, Parrini E, Olds C, Barkovich AJ, Guerrini R, Dobyns WB. Lissencephaly: Expanded imaging and clinical classification. Am J Med Genet A 2017;173:1473-88.

5. Abdollahi MR, Morrison E, Sirey T, Molnar Z, Hayward BE, Carr IM, Springell K, Woods CG, Ahmed M, Hattingh L, Corry P, Pilz DT, Stoodley N, Crow Y, Taylor GR, Bonthron DT, Sheridan E. Mutation of the variant alpha-tubulin TUBA8 results in polymicrogyria with optic nerve hypoplasia. Am J Hum Genet 2009;85:737-44.

6. Rivière JB, van Bon BW, Hoischen A, Kholmanskikh SS, O'Roak BJ, Gilissen C, Gijsen S, Sullivan CT, Christian SL, Abdul-Rahman OA, Atkin JF, Chassaing N, DrouinGarraud V, Fry AE, Fryns JP, Gripp KW, Kempers M, Kleefstra T, Mancini GM, Nowaczyk MJ, van RavenswaaijArts CM, Roscioli T, Marble M, Rosenfeld JA, Siu VM, de Vries BB, Shendure J, Verloes A, Veltman JA, Brunner HG, Ross ME, Pilz DT, Dobyns WB. De novo mutations in the actin genes ACTB and ACTG1 cause Baraitser-
Winter syndrome. Nat Genet 2012;44:440-4, S1-2.

7. Willemsen MH, Vissers LE, Willemsen MA, van Bon BW, Kroes T, de Ligt J, de Vries BB, Schoots J, Lugtenberg D, Hamel BC, van Bokhoven H, Brunner HG, Veltman JA, Kleefstra T. Mutations in DYNC1H1 cause severe intellectual disability with neuronal migration defects. J Med Genet 2012;49:179-83.

8. Boycott KM, Bonnemann C, Herz J, Neuert S, Beaulieu C, Scott JN, Venkatasubramanian A, Parboosingh JS. Mutations in VLDLR as a cause for autosomal recessive cerebellar ataxia with mental retardation (dysequilibrium syndrome). J Child Neurol 2009;24:1310-5.

9. Breuss M, Heng JI, Poirier K, Tian G, Jaglin XH, Qu Z, Braun A, Gstrein T, Ngo L, Haas M, Bahi-Buisson N, Moutard ML, Passemard S, Verloes A, Gressens P, Xie Y, Robson KJ, Rani DS, Thangaraj K, Clausen T, Chelly J, Cowan NJ, Keays DA. Mutations in the $\beta$-tubulin gene TUBB5 cause microcephaly with structural brain abnormalities. Cell Rep 2012;2:1554-62.

10. Di Donato N, Jean YY, Maga AM, Krewson BD, Shupp AB, Avrutsky MI, Roy A, Collins S, Olds C, Willert RA, Czaja AM, Johnson R, Stover JA, Gottlieb S, Bartholdi D, Rauch A, Goldstein A, Boyd-Kyle V, Aldinger KA, Mirzaa GM, Nissen A, Brigatti KW, Puffenberger EG, Millen KJ, Strauss KA, Dobyns WB, Troy CM, Jinks RN. Mutations in CRADD Result in Reduced Caspase-2Mediated Neuronal Apoptosis and Cause Megalencephaly with a Rare Lissencephaly Variant. Am J Hum Genet 2016;99:1117-29.

11. Hong SE, Shugart YY, Huang DT, Shahwan SA, Grant PE, Hourihane JO, Martin ND, Walsh CA. Autosomal recessive lissencephaly with cerebellar hypoplasia is associated with human RELN mutations. Nat Genet 2000;26:93-6.

12. Jaglin XH, Poirier K, Saillour Y, Buhler E, Tian G, BahiBuisson N, Fallet-Bianco C, Phan-Dinh-Tuy F, Kong XP, Bomont P, Castelnau-Ptakhine L, Odent S, Loget P, Kossorotoff M, Snoeck I, Plessis G, Parent P, Beldjord C, Cardoso C, Represa A, Flint J, Keays DA, Cowan NJ, Chelly J. Mutations in the beta-tubulin gene TUBB2B result in asymmetrical polymicrogyria. Nat Genet 2009;41:746-52.

13. Keays DA, Tian G, Poirier K, Huang GJ, Siebold C, Cleak J, Oliver PL, Fray M, Harvey RJ, Molnár Z, Piñon MC, Dear N, Valdar W, Brown SD, Davies KE, Rawlins JN, Cowan NJ, Nolan P, Chelly J, Flint J. Mutations in alpha-tubulin cause abnormal neuronal migration in mice and lissencephaly in humans. Cell 2007;128:45-57. 
14. Kitamura K, Yanazawa M, Sugiyama N, Miura H, IizukaKogo A, Kusaka M, Omichi K, Suzuki R, Kato-Fukui Y, Kamiirisa K, Matsuo M, Kamijo S, Kasahara M, Yoshioka H, Ogata T, Fukuda T, Kondo I, Kato M, Dobyns WB, Yokoyama M, Morohashi K. Mutation of ARX causes abnormal development of forebrain and testes in mice and $\mathrm{X}$-linked lissencephaly with abnormal genitalia in humans. Nat Genet 2002;32:359-69.

15. Poirier K, Lebrun N, Broix L, Tian G, Saillour Y, Boscheron C, Parrini E, Valence S, Pierre BS, Oger M, Lacombe D, Geneviève D, Fontana E, Darra F, Cances C, Barth M, Bonneau D, Bernadina BD, N'guyen S, Gitiaux C, Parent P, des Portes V, Pedespan JM, Legrez V, Castelnau-Ptakine L, Nitschke P, Hieu T, Masson C, Zelenika D, Andrieux A, Francis F, Guerrini R, Cowan NJ, Bahi-Buisson N, Chelly J. Mutations in TUBG1, DYNC1H1, KIF5C and KIF2A cause malformations of cortical development and microcephaly. Nat Genet 2013;45:639-47.

16. Herbst SM, Proepper CR, Geis T, Borggraefe I, Hahn A, Debus O, Haeussler M, von Gersdorff G, Kurlemann G, Ensslen M, Beaud N, Budde J, Gilbert M, Heiming R, Morgner R, Philippi H, Ross S, Strobl-Wildemann G, Muelleder K, Vosschulte P, Morris-Rosendahl DJ, Schuierer G, Hehr U. LIS1-associated classic lissencephaly: A retrospective, multicenter survey of the epileptogenic phenotype and response to antiepileptic drugs. Brain Dev 2016;38:399-406.

17. Cardoso C, Leventer RJ, Ward HL, Toyo-Oka K, Chung J, Gross A, Martin CL, Allanson J, Pilz DT, Olney AH, Mutchinick OM, Hirotsune S, Wynshaw-Boris A, Dobyns WB, Ledbetter DH. Refinement of a 400-kb critical region allows genotypic differentiation between isolated lissencephaly, Miller-Dieker syndrome, and other phenotypes secondary to deletions of 17 p13.3. Am J Hum Genet 2003;72:918-30.

18. Classen S, Goecke T, Drechsler M, et al. A novel inverted 17p13.3 microduplication disrupting PAFAH1B1 (LIS1) in a girl with syndromic lissencephaly. Am J Med Genet A 2013;161A:1453-8.

19. Toyo-oka K, Shionoya A, Gambello MJ, Cardoso C, Leventer R, Ward HL, Ayala R, Tsai LH, Dobyns W, Ledbetter D, Hirotsune S, Wynshaw-Boris A. 14-3-3 epsilon is important for neuronal migration by binding to NUDEL: a molecular explanation for MillerDieker syndrome. Nat Genet 2003;34:274-85.

20. Nagamani SC, Zhang F, Shchelochkov OA, Bi W, Ou Z, Scaglia F, Probst FJ, Shinawi M, Eng C, Hunter JV,
Sparagana S, Lagoe E, Fong CT, Pearson M, DocoFenzy M, Landais E, Mozelle M, Chinault AC, Patel A, Bacino CA, Sahoo T, Kang SH, Cheung SW, Lupski JR, Stankiewicz P. Microdeletions including YWHAE in the Miller-Dieker syndrome region on chromosome 17p13.3 result in facial dysmorphisms, growth restriction, and cognitive impairment. J Med Genet 2009;46:825-33.

21. Mignon-Ravix C, Cacciagli P, El-Waly B, Moncla A, Milh M, Girard N, Chabrol B, Philip N, Villard L. Deletion of YWHAE in a patient with periventricular heterotopias and pronounced corpus callosum hypoplasia. J Med Genet 2010;47:132-6.

22. Mei D, Lewis R, Parrini E, Lazarou LP, Marini C, Pilz DT, Guerrini R. High frequency of genomic deletions-and a duplication--in the LIS1 gene in lissencephaly: implications for molecular diagnosis. J Med Genet 2008;45:355-61.

23. Sicca F, Kelemen A, Genton P, Das S, Mei D, Moro F, Dobyns WB, Guerrini R. Mosaic mutations of the LIS1 gene cause subcortical band heterotopia. Neurology 2003;61:1042-6.

24. Lo Nigro C, Chong CS, Smith AC, Dobyns WB, Carrozzo R, Ledbetter DH. Point mutations and an intragenic deletion in LIS1, the lissencephaly causative gene in isolated lissencephaly sequence and Miller-Dieker syndrome. Hum Mol Genet 1997;6:157-64.

25. D'Agostino MD, Bernasconi A, Das S, Bastos A, Valerio RM, Palmini A, Costa da Costa J, Scheffer IE, Berkovic S, Guerrini R, Dravet C, Ono J, Gigli G, Federico A, Booth F, Bernardi B, Volpi L, Tassinari CA, Guggenheim MA, Ledbetter DH, Gleeson JG, Lopes-Cendes I, Vossler DG, Malaspina E, Franzoni E, Sartori RJ, Mitchell MH, Mercho S, Dubeau F, Andermann F, Dobyns WB, Andermann E. Subcortical band heterotopia (SBH) in males: clinical, imaging and genetic findings in comparison with females. Brain 2002;125:2507-22.

26. Uyanik G, Morris-Rosendahl DJ, Stiegler J, Klapecki J, Gross C, Berman Y, Martin P, Dey L, Spranger S, Korenke GC, Schreyer I, Hertzberg C, Neumann TE, Burkart P, Spaich C, Meng M, Holthausen H, Adès L, Seidel J, Mangold E, Buyse G, Meinecke P, Schara U, Zeschnigk C, Muller D, Helland G, Schulze B, Wright ML, KortgeJung S, Hehr A, Bogdahn U, Schuierer G, Kohlhase J, Aigner L, Wolff G, Hehr U, Winkler J. Location and type of mutation in the LIS1 gene do not predict phenotypic severity. Neurology 2007;69:442-7.

27. Dobyns WB, Truwit CL, Ross ME, Matsumoto N, Pilz DT, Ledbetter DH, Gleeson JG, Walsh CA, Barkovich AJ. 
Differences in the gyral pattern distinguish chromosome 17-linked and X-linked lissencephaly. Neurology 1999;53:270-7.

28. Saillour Y, Carion N, Quelin C, Leger PL, Boddaert N, Elie C, Toutain A, Mercier S, Barthez MA, Milh M, Joriot S, des Portes V, Philip N, Broglin D, Roubertie A, Pitelet G, Moutard ML, Pinard JM, Cances C, Kaminska A, Chelly J, Beldjord C, Bahi-Buisson N. LIS1related isolated lissencephaly: spectrum of mutations and relationships with malformation severity. Arch Neurol 2009;66:1007-15.

29. Dobyns WB, Das S. LIS1-Associated Lissencephaly/ Subcortical Band Heterotopia. In: Adam MP, Ardinger HH, Pagon RA, Wallace SE, Bean LJ, Stephens K, Amemiya A. GeneReviews®. Seattle (WA): University of Washington, Seattle, 1993.

30. Horesh D, Sapir T, Francis F, Wolf SG, Caspi M, Elbaum M, Chelly J, Reiner O. Doublecortin, a stabilizer of microtubules. Hum Mol Genet 1999;8:1599-610.

31. Tanaka T, Serneo FF, Higgins C, Gambello MJ, Wynshaw-Boris A, Gleeson JG. Lis1 and doublecortin function with dynein to mediate coupling of the nucleus to the centrosome in neuronal migration. J Cell Biol 2004;165:709-21.

32. Matsumoto N, Leventer RJ, Kuc JA, Mewborn SK, Dudlicek LL, Ramocki MB, Pilz DT, Mills PL, Das S, Ross ME, Ledbetter DH, Dobyns WB. Matsumoto N1, Leventer RJ, Kuc JA, Mewborn SK, Dudlicek LL, Ramocki MB, Pilz DT, Mills PL, Das S, Ross ME, Ledbetter DH, Dobyns WB. Eur J Hum Genet 2001;9:5-12.

33. Gleeson JG, Minnerath S, Kuzniecky RI, Dobyns WB, Young ID, Ross ME, Walsh CA. Somatic and germline mosaic mutations in the doublecortin gene are associated with variable phenotypes. Am J Hum Genet 2000;67:574-81.

34. Aigner L, Uyanik G, Couillard-Despres S, Ploetz S, Wolff G, Morris-Rosendahl D, Martin P, Eckel U, Spranger S, Otte J, Woerle H, Holthausen H, Apheshiotis N, Fluegel $\mathrm{D}$, Winkler J. Somatic mosaicism and variable penetrance in doublecortin-associated migration disorders. Neurology 2003;60:329-32.

35. Hehr U, Uyanik G, Aigner L, Couillard-Despres S, Winkler J. DCX-Related Disorders. In: Adam MP, Ardinger HH, Pagon RA, Wallace SE, Bean LJ, Stephens K, Amemiya A. GeneReviews®. Seattle (WA): University of Washington, Seattle, 1993.

36. Leger PL, Souville I, Boddaert N, Elie C, Pinard JM, Plouin P, Moutard ML, des Portes V, Van Esch H, Joriot S, Renard JL, Chelly J, Francis F, Beldjord C, Bahi-Buisson
$\mathrm{N}$. The location of DCX mutations predicts malformation severity in X-linked lissencephaly. Neurogenetics 2008;9:277-85.

37. Palmini A, Andermann F, Aicardi J, Dulac O, Chaves F, Ponsot G, Pinard JM, Goutières F, Livingston J, Tampieri D, Andermann E, Robitaille Y. Diffuse cortical dysplasia, or the 'double cortex' syndrome: the clinical and epileptic spectrum in 10 patients. Neurology 1991;41:1656-62.

38. Barkovich AJ, Guerrini R, Battaglia G, Kalifa G, N'Guyen T, Parmeggiani A, Santucci M, Giovanardi-Rossi P, Granata T, D'Incerti L. Band heterotopia: correlation of outcome with magnetic resonance imaging parameters. Ann Neurol 1994;36:609-17.

39. Bahi-Buisson N, Poirier K, Fourniol F, Saillour Y, Valence S, Lebrun N, Hully M, Bianco CF, Boddaert N, Elie C, Lascelles K, Souville I; LIS-Tubulinopathies Consortium, Beldjord C, Chelly J. The wide spectrum of tubulinopathies: what are the key features for the diagnosis? Brain 2014;137:1676-700.

40. Mutch CA, Poduri A, Sahin M, Barry B, Walsh CA, Barkovich AJ. Disorders of Microtubule Function in Neurons: Imaging Correlates. AJNR Am J Neuroradiol 2016;37:528-35.

41. Bahi-Buisson N, Cavallin M. Tubulinopathies Overview. In: Adam MP, Ardinger HH, Pagon RA, Wallace SE, Bean LJ, Stephens K, Amemiya A. GeneReviews®. Seattle (WA): University of Washington, Seattle, 1993.

42. Chew S, Balasubramanian R, Chan WM, Kang PB, Andrews C, Webb BD, MacKinnon SE, Oystreck DT, Rankin J, Crawford TO, Geraghty M, Pomeroy SL, Crowley WF Jr, Jabs EW, Hunter DG, Grant PE, Engle EC. A novel syndrome caused by the $\mathrm{E} 410 \mathrm{~K}$ amino acid substitution in the neuronal $\beta$-tubulin isotype 3 . Brain 2013;136:522-35.

43. Poirier K, Keays DA, Francis F, Saillour Y, Bahi N, Manouvrier S, Fallet-Bianco C, Pasquier L, Toutain A, Tuy FP, Bienvenu T, Joriot S, Odent S, Ville D, Desguerre I, Goldenberg A, Moutard ML, Fryns JP, van Esch H, Harvey RJ, Siebold C, Flint J, Beldjord C, Chelly J. Large spectrum of lissencephaly and pachygyria phenotypes resulting from de novo missense mutations in tubulin alpha 1A (TUBA1A). Hum Mutat 2007;28:1055-64.

44. Lewis SA, Lee MG, Cowan NJ. Five mouse tubulin isotypes and their regulated expression during development. J Cell Biol 1985;101:852-61.

45. Miller FD, Naus CC, Durand M, Bloom FE, Milner RJ. Isotypes of alpha-tubulin are differentially regulated during neuronal maturation. J Cell Biol 1987;105:3065-73. 
46. Poirier K, Saillour Y, Fourniol F, Francis F, Souville I, Valence S, Desguerre I, Marie Lepage J, Boddaert N, Line Jacquemont M, Beldjord C, Chelly J, BahiBuisson N. Expanding the spectrum of TUBA1A-related cortical dysgenesis to Polymicrogyria. Eur J Hum Genet 2013;21:381-5.

47. Bahi-Buisson N, Poirier K, Boddaert N, Saillour Y, Castelnau L, Philip N, Buyse G, Villard L, Joriot S, Marret S, Bourgeois M, Van Esch H, Lagae L, Amiel J, Hertz-Pannier L, Roubertie A, Rivier F, Pinard JM, Beldjord C, Chelly J. Refinement of cortical dysgeneses spectrum associated with TUBA1A mutations. J Med Genet 2008;45:647-53.

48. Kumar RA, Pilz DT, Babatz TD, Cushion TD, Harvey K, Topf M, Yates L, Robb S, Uyanik G, Mancini GM, Rees MI, Harvey RJ, Dobyns WB. TUBA1A mutations cause wide spectrum lissencephaly (smooth brain) and suggest that multiple neuronal migration pathways converge on alpha tubulins. Hum Mol Genet 2010;19:2817-27.

49. Fallet-Bianco C, Laquerrière A, Poirier K, Razavi F, Guimiot F, Dias P, Loeuillet L, Lascelles K, Beldjord C, Carion N, Toussaint A, Revencu N, Addor MC, Lhermitte B, Gonzales M, Martinovich J, Bessieres B, Marcy-Bonnière $\mathrm{M}$, Jossic F, Marcorelles $\mathrm{P}$, Loget $\mathrm{P}$, Chelly J, Bahi-Buisson N. Mutations in tubulin genes are frequent causes of various foetal malformations of cortical development including microlissencephaly. Acta Neuropathol Commun 2014;2:69.

50. Myers KA, Bello-Espinosa LE, Kherani A, Wei XC, Innes AM. TUBA1A Mutation Associated With Eye Abnormalities in Addition to Brain Malformation. Pediatr Neurol 2015;53:442-4.

51. Crabtree DV, Ojima I, Geng X, Adler AJ. Tubulins in the primate retina: evidence that xanthophylls may be endogenous ligands for the paclitaxel-binding site. Bioorg Med Chem 2001;9:1967-76.

52. Jansen AC, Oostra A, Desprechins B, De Vlaeminck Y, Verhelst H, Régal L, Verloo P, Bockaert N, Keymolen K, Seneca S, De Meirleir L, Lissens W. TUBA1A mutations: from isolated lissencephaly to familial polymicrogyria. Neurology 2011;76:988-92.

53. Zanni G, Colafati GS, Barresi S, Randisi F, Talamanca LF, Genovese E, Bellacchio E, Bartuli A, Bernardi B, Bertini E. Description of a novel TUBA1A mutation in Arg-390 associated with asymmetrical polymicrogyria and midhindbrain dysgenesis. Eur J Paediatr Neurol 2013;17:361-5.

54. Cushion TD, Dobyns WB, Mullins JG, Stoodley N, Chung SK, Fry AE, Hehr U, Gunny R, Aylsworth AS,
Prabhakar P, Uyanik G, Rankin J, Rees MI, Pilz DT. Overlapping cortical malformations and mutations in TUBB2B and TUBA1A. Brain 2013;136:536-48.

55. Aiken J, Buscaglia G, Bates EA, Moore JK. The $\alpha$-Tubulin gene TUBA1A in Brain Development: A Key Ingredient in the Neuronal Isotype Blend. J Dev Biol 2017;5. doi: 10.3390/jdb5030008.

56. Cederquist GY, Luchniak A, Tischfield MA, Peeva M, Song Y, Menezes MP, Chan WM, Andrews C, Chew S, Jamieson RV, Gomes L, Flaherty M, Grant PE, Gupta ML Jr, Engle EC. An inherited TUBB2B mutation alters a kinesinbinding site and causes polymicrogyria, CFEOM and axon dysinnervation. Hum Mol Genet 2012;21:5484-99.

57. Guerrini R, Mei D, Cordelli DM, Pucatti D, Franzoni E, Parrini E. Symmetric polymicrogyria and pachygyria associated with TUBB2B gene mutations. Eur J Hum Genet 2012;20:995-8.

58. Romaniello R, Tonelli A, Arrigoni F, Baschirotto C, Triulzi F, Bresolin N, Bassi MT, Borgatti R. A novel mutation in the $\beta$-tubulin gene TUBB2B associated with complex malformation of cortical development and deficits in axonal guidance. Dev Med Child Neurol 2012;54:765-9.

59. Cushion TD, Paciorkowski AR, Pilz DT, Mullins JG, Seltzer LE, Marion RW, Tuttle E, Ghoneim D, Christian SL, Chung SK, Rees MI, Dobyns WB. De novo mutations in the beta-tubulin gene TUBB2A cause simplified gyral patterning and infantile-onset epilepsy. Am J Hum Genet 2014;94:634-41.

60. Marcorelles P, Laquerrière A, Adde-Michel C, Marret S, Saugier-Veber P, Beldjord C, Friocourt G. Evidence for tangential migration disturbances in human lissencephaly resulting from a defect in LIS1, DCX and ARX genes. Acta Neuropathol 2010;120:503-15.

61. Kato M, Dobyns WB. X-linked lissencephaly with abnormal genitalia as a tangential migration disorder causing intractable epilepsy: proposal for a new term, "interneuronopathy". J Child Neurol 2005;20:392-7.

62. Kato M. Genotype-phenotype correlation in neuronal migration disorders and cortical dysplasias. Front Neurosci 2015;9:181.

63. Kato M, Dobyns WB. Lissencephaly and the molecular basis of neuronal migration. Hum Mol Genet 2003;12 Spec No 1:R89-96.

64. Moon HM, Wynshaw-Boris A. Cytoskeleton in action: lissencephaly, a neuronal migration disorder. Wiley Interdiscip Rev Dev Biol 2013;2:229-45.

65. D'Arcangelo G, Miao GG, Chen SC, Soares HD, Morgan JI, Curran T. A protein related to extracellular matrix 
proteins deleted in the mouse mutant reeler. Nature 1995;374:719-23.

66. DeSilva U, D'Arcangelo G, Braden VV, Chen J, Miao GG, Curran T, Green ED. The human reelin gene: isolation, sequencing, and mapping on chromosome 7. Genome Res 1997;7:157-64.

67. Boycott KM, Flavelle S, Bureau A, Glass HC, Fujiwara TM, Wirrell E, Davey K, Chudley AE, Scott JN, McLeod DR, Parboosingh JS. Homozygous deletion of the very low density lipoprotein receptor gene causes autosomal recessive cerebellar hypoplasia with cerebral gyral simplification. Am J Hum Genet 2005;77:477-83.

68. Ozcelik T, Akarsu N, Uz E, Caglayan S, Gulsuner S, Onat OE, Tan M, Tan U. Mutations in the very low-density lipoprotein receptor VLDLR cause cerebellar hypoplasia and quadrupedal locomotion in humans. Proc Natl Acad Sci U S A 2008;105:4232-6.

69. Norman MG, Roberts M, Sirois J, Tremblay LJ. Lissencephaly. Can J Neurol Sci 1976;3:39-46.

70. Caksen H, Tuncer O, Kirimi E, Fryns JP, Uner A, Unal O, Cinal A, Odabaş D. Report of two Turkish infants with Norman-Roberts syndrome. Genet Couns 2004;15:9-17.

71. Sergi C, Zoubaa S, Schiesser M. Norman-Roberts syndrome: prenatal diagnosis and autopsy findings. Prenat Diagn 2000;20:505-9.

72. Magen D, Ofir A, Berger L, Goldsher D, Eran A, Katib N, Nijem Y, Vlodavsky E, Tzur S, Behar DM, Fellig Y, Mandel H. Autosomal recessive lissencephaly with cerebellar hypoplasia is associated with a loss-of-function mutation in CDK5. Hum Genet 2015;134:305-14. Erratum in: Hum Genet 2015;134:315. Katib, Nassser [corrected to Katib, Nasser]; Zur, Shay [corrected to Tzur, Shay].

73. Su SC, Tsai LH. Cyclin-dependent kinases in brain development and disease. Annu Rev Cell Dev Biol 2011;27:465-91.

74. Niethammer M, Smith DS, Ayala R, Peng J, Ko J, Lee MS, Morabito M, Tsai LH. NUDEL is a novel Cdk5 substrate that associates with LIS1 and cytoplasmic dynein. Neuron 2000;28:697-711.

75. Tanaka T, Serneo FF, Tseng HC, Kulkarni AB, Tsai LH, Gleeson JG. Cdk5 phosphorylation of doublecortin ser297 regulates its effect on neuronal migration. Neuron 2004;41:215-27.

76. Ohshima T, Ward JM, Huh CG, Longenecker G, Veeranna, Pant HC, Brady RO, Martin LJ, Kulkarni AB. Targeted disruption of the cyclin-dependent kinase 5 gene results in abnormal corticogenesis, neuronal pathology and perinatal death. Proc Natl Acad Sci U S A 1996;93:11173-8.

77. Ko J, Humbert S, Bronson RT, Takahashi S, Kulkarni AB, Li E, Tsai LH. p35 and p39 are essential for cyclindependent kinase 5 function during neurodevelopment. J Neurosci 2001;21:6758-71.

78. Kumazawa A, Mita N, Hirasawa M, Adachi T, Suzuki H, Shafeghat N, Kulkarni AB, Mikoshiba K, Inoue T, Ohshima T. Cyclin-dependent kinase 5 is required for normal cerebellar development. Mol Cell Neurosci 2013;52:97-105.

79. Gilmore EC, Ohshima T, Goffinet AM, Kulkarni AB, Herrup K. Cyclin-dependent kinase 5-deficient mice demonstrate novel developmental arrest in cerebral cortex. J Neurosci 1998;18:6370-7.

80. Friocourt G, Marcorelles P, Saugier-Veber P, Quille ML, Marret S, Laquerrière A. Role of cytoskeletal abnormalities in the neuropathology and pathophysiology of type I lissencephaly. Acta Neuropathol 2011;121:149-70.

81. Miyamoto T, Hosoba K, Ochiai H, Royba E, Izumi H, Sakuma T, Yamamoto T, Dynlacht BD, Matsuura S. The Microtubule-Depolymerizing Activity of a Mitotic Kinesin Protein KIF2A Drives Primary Cilia Disassembly Coupled with Cell Proliferation. Cell Rep 2015. doi: 10.1016/ j.celrep.2015.01.003. [Epub ahead of print].

82. Putoux A, Thomas S, Coene KL, Davis EE, Alanay Y, Ogur G, Uz E, Buzas D, Gomes C, Patrier S, Bennett CL, Elkhartoufi N, Frison MH, Rigonnot L, Joyé N, Pruvost S, Utine GE, Boduroglu K, Nitschke P, Fertitta L, ThauvinRobinet C, Munnich A, Cormier-Daire V, Hennekam R, Colin E, Akarsu NA, Bole-Feysot C, Cagnard N, Schmitt A, Goudin N, Lyonnet S, Encha-Razavi F, Siffroi JP, Winey M, Katsanis N, Gonzales M, Vekemans M, Beales PL, Attié-Bitach T. KIF7 mutations cause fetal hydrolethalus and acrocallosal syndromes. Nat Genet 2011;43:601-6.

83. Dafinger C, Liebau MC, Elsayed SM, Hellenbroich Y, Boltshauser E, Korenke GC, Fabretti F, Janecke AR, Ebermann I, Nürnberg G, Nürnberg P, Zentgraf H, Koerber F, Addicks K, Elsobky E, Benzing T, Schermer B, Bolz HJ. Mutations in KIF7 link Joubert syndrome with Sonic Hedgehog signaling and microtubule dynamics. J Clin Invest 2011;121:2662-7.

84. Willemsen MH, Ba W, Wissink-Lindhout WM, de Brouwer AP, Haas SA, Bienek M, Hu H, Vissers LE, van Bokhoven H, Kalscheuer V, Nadif Kasri N, Kleefstra T. Involvement of the kinesin family members KIF4A and $\mathrm{KIF} 5 \mathrm{C}$ in intellectual disability and synaptic function. J Med Genet 2014;51:487-94. 
85. Cavallin M, Hubert L, Cantagrel V, Munnich A, Boddaert N, Vincent-Delorme C, Cuvellier JC, Masson C, Besmond C, Bahi-Buisson N. Recurrent KIF5C mutation leading to frontal pachygyria without microcephaly. Neurogenetics 2016;17:79-82.

86. Cavallin M, Bijlsma EK, El Morjani A, Moutton S, Peeters EA, Maillard C, Pedespan JM, Guerrot AM, Drouin-Garaud V, Coubes C, Genevieve D, Bole-Feysot C, Fourrage C, Steffann J, Bahi-Buisson N. Recurrent KIF2A mutations are responsible for classic lissencephaly. Neurogenetics 2017;18:73-79.

87. Homma N, Takei Y, Tanaka Y, Nakata T, Terada S, Kikkawa M, Noda Y, Hirokawa N. Kinesin superfamily protein $2 \mathrm{~A}$ (KIF2A) functions in suppression of collateral branch extension. Cell 2003;114:229-39.

88. Jamuar SS, Lam AT, Kircher M, D'Gama AM, Wang J, Barry BJ, Zhang X, Hill RS, Partlow JN, Rozzo A, Servattalab S, Mehta BK, Topcu M, Amrom D, Andermann E, Dan B, Parrini E, Guerrini R, Scheffer IE, Berkovic SF, Leventer RJ, Shen Y, Wu BL, Barkovich AJ, Sahin M, Chang BS, Bamshad M, Nickerson DA, Shendure J, Poduri A, Yu TW, Walsh CA. Somatic mutations in cerebral cortical malformations. N Engl J Med 2014;371:733-43.

89. Michels S, Foss K, Park K, Golden-Grant K, Saneto R, Lopez J, Mirzaa GM. Mutations of KIF5C cause a neurodevelopmental disorder of infantile-onset epilepsy, absent language, and distinctive malformations of cortical development. Am J Med Genet A 2017;173:3127-31.

90. Padzik A, Deshpande P, Hollos P, Franker M, Rannikko EH, Cai D, Prus P, Mågård M, Westerlund N, Verhey KJ, James P, Hoogenraad CC, Coffey ET. KIF5C S176 Phosphorylation Regulates Microtubule Binding and Transport Efficiency in Mammalian Neurons. Front Cell Neurosci 2016;10:57.

91. Weedon MN, Hastings R, Caswell R, Xie W, Paszkiewicz K, Antoniadi T, Williams M, King C, Greenhalgh L, Newbury-Ecob R, Ellard S. Exome sequencing identifies a DYNC1H1 mutation in a large pedigree with dominant axonal Charcot-Marie-Tooth disease. Am J Hum Genet 2011;89:308-12.

92. Harms MB, Ori-McKenney KM, Scoto M, Tuck EP, Bell S, Ma D, Masi S, Allred P, Al-Lozi M, Reilly MM, Miller LJ, Jani-Acsadi A, Pestronk A, Shy ME, Muntoni F, Vallee RB, Baloh RH. Mutations in the tail domain of DYNC1H1 cause dominant spinal muscular atrophy. Neurology 2012;78:1714-20.

93. Tsurusaki Y, Saitoh S, Tomizawa K, Sudo A, Asahina N,
Shiraishi H, Ito J, Tanaka H, Doi H, Saitsu H, Miyake N, Matsumoto N. A DYNC1H1 mutation causes a dominant spinal muscular atrophy with lower extremity predominance. Neurogenetics 2012;13:327-32.

94. de Ligt J, Willemsen MH, van Bon BW, Kleefstra T, Yntema HG, Kroes T, Vulto-van Silfhout AT, Koolen DA, de Vries P, Gilissen C, del Rosario M, Hoischen A, Scheffer H, de Vries BB, Brunner HG, Veltman JA, Vissers LE. Diagnostic exome sequencing in persons with severe intellectual disability. N Engl J Med 2012;367:1921-9.

95. Vallee RB, Tsai JW. The cellular roles of the lissencephaly gene LIS1, and what they tell us about brain development. Genes Dev 2006;20:1384-93.

96. Sasaki S, Shionoya A, Ishida M, Gambello MJ, Yingling J, Wynshaw-Boris A, Hirotsune S. A LIS1/NUDEL/ cytoplasmic dynein heavy chain complex in the developing and adult nervous system. Neuron 2000;28:681-96.

97. Yamada M, Hirotsune S, Wynshaw-Boris A. The essential role of LIS1, NDEL1 and Aurora-A in polarity formation and microtubule organization during neurogensis. Cell Adh Migr 2010;4:180-4.

98. Alkuraya FS, Cai X, Emery C, Mochida GH, Al-Dosari MS, Felie JM, Hill RS, Barry BJ, Partlow JN, Gascon GG, Kentab A, Jan M, Shaheen R, Feng Y, Walsh CA. Human mutations in NDE1 cause extreme microcephaly with lissencephaly [corrected]. Am J Hum Genet 2011;88:53647. Erratum in: Am J Hum Genet 2011;88:677.

99. Bakircioglu M, Carvalho OP, Khurshid M, Cox JJ, Tuysuz B, Barak T, Yilmaz S, Caglayan O, Dincer A, Nicholas AK, Quarrell O, Springell K, Karbani G, Malik S, Gannon C, Sheridan E, Crosier M, Lisgo SN, Lindsay S, Bilguvar K, Gergely F, Gunel M, Woods CG. The essential role of centrosomal NDE1 in human cerebral cortex neurogenesis. Am J Hum Genet 2011;88:523-35.

100. Guven A, Gunduz A, Bozoglu TM, Yalcinkaya C, Tolun A. Novel NDE1 homozygous mutation resulting in microhydranencephaly and not microlyssencephaly. Neurogenetics 2012;13:189-94.

101. Duan H, Dixit VM. RAIDD is a new 'death' adaptor molecule. Nature 1997;385:86-9.

102.Perrin BJ, Ervasti JM. The actin gene family: function follows isoform. Cytoskeleton (Hoboken) 2010;67:630-4.

103.Liu JS. Molecular genetics of neuronal migration disorders. Curr Neurol Neurosci Rep 2011;11:171-8.

104. Verloes A, Di Donato N, Masliah-Planchon J, Jongmans M, Abdul-Raman OA, Albrecht B, Allanson J, Brunner H, Bertola D, Chassaing N, David A, Devriendt K, Eftekhari P, Drouin-Garraud V, Faravelli F, Faivre L, Giuliano 
F, Guion Almeida L, Juncos J, Kempers M, Eker HK, Lacombe D, Lin A, Mancini G, Melis D, Lourenço CM, Siu VM, Morin G, Nezarati M, Nowaczyk MJ, Ramer JC, Osimani S, Philip N, Pierpont ME, Procaccio V, Roseli ZS, Rossi M, Rusu C, Sznajer Y, Templin L, Uliana V, Klaus M, Van Bon B, Van Ravenswaaij C, Wainer B, Fry AE, Rump A, Hoischen A, Drunat S, Rivière JB, Dobyns WB, Pilz DT. Baraitser-Winter cerebrofrontofacial syndrome: delineation of the spectrum in 42 cases. Eur J Hum Genet 2015;23:292-301.

105. Rossi M, Guerrini R, Dobyns WB, Andria G, Winter $\mathrm{RM}$. Characterization of brain malformations in the Baraitser-Winter syndrome and review of the literature. Neuropediatrics 2003;34:287-92.

106. Shiihara T, Maruyama K, Yamada Y, Nishimura A, Matsumoto N, Kato M, Sakazume S. A case of Baraitser-Winter syndrome with unusual brain MRI findings: pachygyria, subcortical-band heterotopia, and periventricular heterotopia. Brain Dev 2010;32:502-5.

Cite this article as: Tan AP, Chong WK, Mankad K. Comprehensive genotype-phenotype correlation in lissencephaly. Quant Imaging Med Surg 2018;8(7):673-693. doi: 10.21037/qims.2018.08.08
107.Johnston JJ, Wen KK, Keppler-Noreuil K, McKane M, Maiers JL, Greiner A, Sapp JC; NIH Intramural Sequencing Center, Demali KA, Rubenstein PA, Biesecker LG. Functional analysis of a de novo ACTB mutation in a patient with atypical Baraitser-Winter syndrome. Hum Mutat 2013;34:1242-9.

108. Di Donato N, Kuechler A, Vergano S, Heinritz W, Bodurtha J, Merchant SR, Breningstall G, Ladda R, Sell S, Altmüller J, Bögershausen N, Timms AE, Hackmann K, Schrock E, Collins S, Olds C, Rump A, Dobyns WB. Update on the ACTG1-associated Baraitser-Winter cerebrofrontofacial syndrome. Am J Med Genet A 2016;170:2644-51.

109. Verloes A, Drunat S, Pilz D, Di Donato N. BaraitserWinter Cerebrofrontofacial Syndrome. In: Adam MP, Ardinger HH, Pagon RA, Wallace SE, Bean LJ, Stephens K, Amemiya A. GeneReviews®. Seattle (WA): University of Washington, Seattle, 1993. 